\title{
Pharmacogenomic Biomarkers for Improved Drug Therapy-Recent Progress and Future Developments
}

\author{
Volker M. Lauschke, ${ }^{1,3}$ Lili Milani, ${ }^{2}$ and Magnus Ingelman-Sundberg ${ }^{1}$
}

Received 24 July 2017; accepted 6 October 2017; published online 27 November 2017

\begin{abstract}
Much of the inter-individual variability in drug efficacy and risk of adverse reactions is due to polymorphisms in genes encoding proteins involved in drug pharmacokinetics and pharmacodynamics or immunological responses. Pharmacogenetic research has identified a multitude of gene-drug response associations, which have resulted in genetically guided treatment and dosing decisions to yield a higher success rate of pharmacological treatment. The rapid technological developments for genetic analyses reveal that the number of genetic variants with importance for drug action is much higher than previously thought and that a true personalized prediction of drug response requires attention to millions of rare mutations. Here, we review the evolutionary background of genetic polymorphisms in drugmetabolizing enzymes, provide some important examples of current use of pharmacogenomic biomarkers, and give an update of germline and somatic genome biomarkers that are in use in drug development and clinical practice. We also discuss the current technology development with emphasis on complex genetic loci, review current initiatives for validation of pharmacogenomic biomarkers, and present scenarios for the future taking rare genetic variants into account for a true personalized genetically guided drug prescription. We conclude that pharmacogenomic information for patient stratification is of value to tailor optimized treatment regimens particularly in oncology. However, the routine use of pharmacogenomic biomarkers in clinical practice in other therapeutic areas is currently sparse and the prospects of its future implementation are being scrutinized by different international consortia.
\end{abstract}

KEY WORDS: precision medicine; cytochrome P450; oncology; clinical implementation; pharmacogenetics.

\section{INTRODUCTION}

Differential response to pharmacological treatment constitutes a major source of patient morbidity and mortality. Between 5 and $13 \%$ of in- and outpatient experience adverse drug-related events, mostly adverse drug reactions (ADRs) and sub-therapeutic effects of drug therapy [1, 2]. Various patient-specific factors, including age, polypharmacy, concomitant diseases, and diet as well as heritable factors contribute to these inter-individual differences with genetic polymor-

\footnotetext{
$\overline{{ }^{1} \text { Department of Physiology and Pharmacology, Section of Phar- }}$ macogenetics, Karolinska Institutet, SE-171 77, Stockholm, Sweden.

${ }^{2}$ Estonian Genome Center, University of Tartu, 51010, Tartu, Estonia.

${ }^{3}$ To whom correspondence should be addressed. (e-mail: volker.lauschke@ki.se)
}

phisms explaining around $20-30 \%$ of the inter-individual variability in drug response [3, 4].

The liver as the central organ of drug metabolism is involved in the clearance of around $70 \%$ of drugs [5]. Enzymes encoded by the cytochrome P450 (CYP) superfamily of genes are responsible for $>75 \%$ of phase 1 drug metabolism and thus constitute major modulators of drug response [6]. Importantly, $C Y P$ genes are highly polymorphic between individuals and across populations, which can have important implications for the bioactivation and/or detoxification of medications [7].

Pharmacogenomic biomarkers that can predict drug response have been attributed great promise for the improvement of molecular diagnostics in routine clinical care. It is helpful to distinguish between (i) germline biomarkers, which can influence systemic drug pharmacokinetics and pharmacodynamics and (ii) biomarkers in the somatic cancer genome, which modulate how cancer cells respond to drugs. Besides genetic factors, epigenetic modifications of DNA or histones have been linked to differences in drug response. In oncology, 
epigenetic alterations in cancer cells have been linked to increased expression of drug efflux transporters, mediating resistance to chemotherapy. Detection of epigenetically modified DNA in the blood stream can be used for tumor stratification and presents an emerging tool for monitoring treatment efficacy as well as development of drug resistance $[8,9]$. Moreover, pharmacological modulators of the epigenetic machinery have been successfully used in oncological treatment, mostly as adjuvants to sensitize tumors to standard-of-care chemotherapy. For a comprehensive update of this field, we refer to recent reviews [10,11].

In this review, we provide an overview of genomic biomarkers that predict drug response and guide choice and dosage of drug treatment. Furthermore, we review recent technological advances that facilitate biomarker discovery and utilization.

\section{DEVELOPMENTAL BACKGROUND FOR THE GENETIC POLYMORPHISM}

The establishment of genetic polymorphisms in a specific population is the result of selection and genetic drift. In case of genes encoding drug absorption, distribution, metabolism, and excretion (ADME), a major selection occurred about 450 million years ago when animals became terrestrial and had to adapt to the novel dietary environment including plant toxins [12]. Among insects several examples are evident where genetic alterations of $C Y P$ genes have enabled the animals to adapt to a new environment caused by the presence of insecticides or a shift of host from one plant to another (Table 1). In humans, a similar adaptation occurred 10,000 to 5000 years ago when a strong selection favored survival of individuals carrying multiple copies of the CYP2D6 gene in Northeast Africa. The mechanism behind the assertion of these duplication alleles is believed to be the resulting increased capability for detoxification of alkaloids in plants allowing a more diversified plant diet during the starvation periods in these areas. The subsequent migration of the respective populations has resulted in an infiltration of these alleles into the Mediterranean area but not to Asia South Africa, or West Africa [19]. Positive selection for gain-offunction alleles is however very rare among ADME genes. By contrast, loss-of-function mutations in ADME genes are often not selected against due to the relatively minor role in endogenous process of the genes, thus constituting the basis for inter-individual differences in drug pharmacokinetics.

\section{PHARMACOGENOMIC GERMLINE BIOMARKERS}

Differences in the response to exogenous substances have already been described more than two millennia ago by the Greek philosopher Pythagoras who noticed in the sixth century before Christ that individuals responded very differently to the ingestion of fava beans with some experiencing severe hemolytic anemia [20]. Excitingly, only in the last decades, technological advances have shed light on the molecular bases underlying these differences and discovered the responsible genetic polymorphisms (in the case of hemolytic responses to fava beans, genetic variants in $G 6 P D$ were found to be responsible for the inter-individual differences in toxicity). By now a whole arsenal of genetic variants has been identified that mechanistically link alterations in structure or functionality of the gene product to differences in drug response or toxicity. Pharmacogenomic biomarkers are mostly located in genes encoding drug-metabolizing enzymes, transporters, drug targets, or HLA alleles and predict drug efficacy or inform about the risk to develop ADRs (Tables 2 and 3). Furthermore, genetic biomarkers have revolutionized the therapy of cystic fibrosis $(\mathrm{CF})$ and we refer the interested readers to some of the recent excellent reviews that cover the field of genetically guided, targeted CF therapy [47, 48].

Genetic variation in genes encoding proteins of importance for drug response and ADRs, herein called pharmacogenes, can cause (i) too high or too low exposure of the drug, (ii) increased formation of toxic metabolites, (iii) increased or decreased interactions with the drug target, or (iv) activation of the immune system which in turn can lead to idiosyncratic drug toxicity (Fig. 1). In the following, we highlight selected pharmacogenomic examples that impact clinical practice and refer to the primary references provided in Tables 2 and 3 as well as to comprehensive recent reviews for further information on the topic [49-51].

Table 1. Examples of Environmentally Induced Genetic Selection of $C Y P$ Gene Amplifications in Animals and Humans

\begin{tabular}{|c|c|c|c|c|}
\hline Species & Gene & Causative agent & Effect & Reference \\
\hline Drosophila mettleri & CYP6, СYP28 & $\begin{array}{l}\text { Isoquinolone } \\
\text { alkaloids }\end{array}$ & $\begin{array}{l}\text { Resistance developed due to induction of } \\
\text { these genes }\end{array}$ & [13] \\
\hline $\begin{array}{l}\text { Fruit fly } \\
\qquad \text { (Drosophila melanogaster) }\end{array}$ & $C Y P 6 G 1$ & DDT & $\begin{array}{l}\text { Amplification of the CYP6G1 gene } \\
\text { causes insecticide resistance }\end{array}$ & [14] \\
\hline $\begin{array}{l}\text { Green house whitefly } \\
\text { (Trialeurodes vaporariorum) }\end{array}$ & CYP4G61 & Pyriproxyfen & $\begin{array}{l}\text { Resistance due to } 81 \text {-fold induction } \\
\text { of } C Y P 4 G 61 \text { expression }\end{array}$ & [15] \\
\hline Honey bee (Apis mellifera) & CYP9Q1, CYP9Q2, CYP9Q3 & $\begin{array}{l}\text { Tau-fluvalinate } \\
\text { and coumaphos }\end{array}$ & Resistance due to $C Y P 9 Q$ induction & [16] \\
\hline Pollen beetle (Meligethes aeneus) & $C Y P 6 B Q 23$ & Pyrethroid & $\begin{array}{l}\text { Up to } 900 \text {-fold overexpression of } \\
C Y P 6 B Q 23 \text { conveys pyrethroid resistance }\end{array}$ & [17] \\
\hline $\begin{array}{l}\text { Green peach aphid } \\
\quad(\text { Myzus persicae })\end{array}$ & СУР6СY3 & Nicotine & $\begin{array}{l}\text { 100-fold amplification of the } C Y P 6 C Y 3 \\
\text { gene allows the insect to feed on } \\
\text { the tobacco plant }\end{array}$ & [18] \\
\hline Homo sapiens & $C Y P 2 D 6$ & Plant alkaloids & $\begin{array}{l}\text { Dietary selection for alleles with } \\
\text { amplifications of the functional } \\
\text { CYP2D6 gene }\end{array}$ & [19] \\
\hline
\end{tabular}


Table 2. Genetic Germline Variants Associated with Adverse Drug Reactions

\begin{tabular}{|c|c|c|c|c|c|}
\hline Class & Genetic variant & Drug & Type of adverse reaction & Odds ratio & Refs \\
\hline \multirow[t]{5}{*}{ Phase I } & $\begin{array}{l}C Y P 2 B 6 \text { reduced function } \\
\text { alleles }\end{array}$ & Efavirenz & Neurological symptoms & $\begin{array}{l}\text { Odds ratio for plasma } \\
\text { concentration above } \\
\text { therapeutic levels: } \\
48.1\end{array}$ & {$[21]$} \\
\hline & CYP2D6 duplications & Codeine & $\begin{array}{l}\text { Symptoms associated } \\
\text { with opioid overdose }\end{array}$ & 1.4 & {$[22]$} \\
\hline & CYP2D6 deficiency & Metoclopramide & Acute dystonic reactions & Only case reports & {$[23]$} \\
\hline & & Perhexiline & Neurotoxicity & Only case reports & {$[24]$} \\
\hline & $\begin{array}{l}D P Y D \text { reduced function } \\
\text { alleles }\end{array}$ & $\begin{array}{l}\text { Fluoropyrimidines } \\
\text { (capecitabine, } \\
\text { fluorouracil and } \\
\text { tegafur) }\end{array}$ & $\begin{array}{l}\text { Severe systemic toxicity, } \\
\text { mainly diarrhea, } \\
\text { neutropenia, } \\
\text { thrombocytopenia } \\
\text { and cardiotoxicity }\end{array}$ & *2A: 15.2; D949V: 9.1 & {$[25]$} \\
\hline \multirow[t]{5}{*}{ Phase II } & GSTM1 null & Isoniazid & DILI & 2.2 & {$[26]$} \\
\hline & GSTT1 null & & DILI & 2.6 & {$[27]$} \\
\hline & $U G T 1 A 1 * 28$ & Irinotecan & $\begin{array}{l}\text { Myelosuppression and } \\
\text { neutropenia }\end{array}$ & 9.3 & {$[28]$} \\
\hline & $U G T 2 B 7 * 2$ & Diclofenac & DILI & 8.5 & {$[29]$} \\
\hline & TPMT deficiency & Mercaptopurine & Myelosuppression & het: 4.6; hom: 18.6 & {$[30]$} \\
\hline Transporter & $\begin{array}{l}\text { Reduced } S L C O 1 B 1 \\
\text { activity (rs4149056) }\end{array}$ & Simvastatin (80 mg daily) & $\begin{array}{l}\text { Myopathy and } \\
\text { rhabdomyolysis }\end{array}$ & het: 4.5 ; hom: 16.9 & {$[31]$} \\
\hline \multirow{12}{*}{$\begin{array}{l}\text { Major } \\
\text { histocompatibility } \\
\text { complex }\end{array}$} & $H L A-B * 57: 01$ & Flucloxacillin & DILI & 80.6 & {$[32]$} \\
\hline & $\begin{array}{l}D R B 1 * 07: 01 \\
\quad \text { and } D Q A * 02: 01\end{array}$ & Ximelagatran & DILI & 4.4 & [33] \\
\hline & $\begin{array}{l}D R B 1 * 15: 01 \text { and } \\
H L A-A * 02: 01 \\
\text { and } H L A-B * 18: 01\end{array}$ & $\begin{array}{l}\text { Amoxicillin- } \\
\text { clavulanate }\end{array}$ & DILI & 10.1 & {$[34]$} \\
\hline & $H L A-A * 33: 03$ & Ticlopidine & DILI & 36.5 & {$[35]$} \\
\hline & $D R B * 15: 01$ and $D Q A * 01: 02$ & Lumiracoxib & DILI & 5 & {$[36]$} \\
\hline & $H L A-B * 57: 01$ & Abacavir & HSS & 117 & {$[37]$} \\
\hline & $H L A-B * 15: 02$ and $H L A-A * 31: 01$ & Carbamazepine & HSS and SJS/TEN & 10.8 & {$[38]$} \\
\hline & $H L A-B * 15: 02$ & Phenytoin & SJS/TEN & 25.2 & [39] \\
\hline & $H L A-B * 58: 01$ & Allopurinol & SJS/TEN & 394 & [40] \\
\hline & $H L A-B * 58: 01$ & Nevirapine & DILI & 3.5 & [41] \\
\hline & $H L A-D R B 1 * 01$ & & DILI & 2.9 & {$[41]$} \\
\hline & $H L A-C^{*} 04: 01$ & & SJS/TEN & 17.5 & {$[42]$} \\
\hline
\end{tabular}

DILI drug-induced liver injury, HSS hypersensitivity syndrome, SJS Stevens-Johnson syndrome, TEN toxic epidermal necrolysis

\section{CLINICALLY IMPORTANT EXAMPLES OF ASSOCIATIONS BETWEEN GENETIC VARIANTS AND DRUG RESPONSE OR TOXICITY}

\section{The Effect of CYP2D6 Genotype on Codeine Efficacy and Toxicity}

Codeine, an analgesic and antitussive opium alkaloid, is $O$ demethylated by CYP2D6 to its active metabolite morphine and CYP2D6 activity constitutes the determining factor for codeine pharmacokinetics. Patients homozygous for loss-of-function haplotypes in $C Y P 2 D 6$, including the $* 4, * 5$, and $* 6$ alleles, experience drastically reduced morphine formation and lack of analgesia. Consequently, in such poor metabolizers (PM), alternative medications that are not metabolized by CYP2D6 should be considered, such as buprenorphine, morphine, fentanyl, methadone, or non-opioid analgesics. In contrast, in ultrarapid metabolizers (UM), in which the active CYP2D6 gene is duplicated, morphine formation is increased and standard codeine doses can result in serum morphine levels that substantially exceed the therapeutic range, resulting in severe toxicity. The risk is highest in pediatric patients who receive codeine following adenotonsillectomy and multiple cases of lifethreatening respiratory depression or death due to codeine therapy have been reported [52]. These severe adverse drug reactions (ADRs) prompted the FDA to require boxed warnings on all codeine-containing medications to highlight the risks for pediatric patients. Furthermore, these cases resulted in a change in routine clinical practice for pain control after tonsillectomy, away from codeine towards other analgesic agents that are not at risk for catastrophic events (e.g., acetaminophen or rofecoxib and hydrocodone) [53].

\section{Warfarin Pharmacogenetics}

Warfarin is the most commonly used oral anticoagulant for the treatment and prevention of thromboembolic events. However, a narrow therapeutic window combined with substantial inter-individual variation in warfarin pharmacokinetics and pharmacodynamics poses severe clinical challenges. Warfarin inhibits 
Table 3. Genetic Germline Variants that Modulate Drug Efficacy

\begin{tabular}{|c|c|c|c|c|}
\hline Drug & Phenotype / Genetic variant & Mechanism & Effect size $\left(R^{2}\right)$ & Refs \\
\hline Codeine & CYP2D6 deficiency & Reduced metabolism to active substance (morphine) & $\begin{array}{l}\text { Expected to be very } \\
\text { high }\end{array}$ & \\
\hline \multirow[t]{4}{*}{ Warfarin } & $\begin{array}{l}\text { Decreased CYP2C } 9 \\
\text { activity }(C Y P 2 C 9 * 2)\end{array}$ & $\begin{array}{l}\text { Reduced inactivation of warfarin. Thus, reduced } \\
\text { VKORC1 inhibition }\end{array}$ & $3.8 \%$ & [43] \\
\hline & $\begin{array}{l}\text { Decreased CYP2C } 9 \\
\text { activity }(C Y P 2 C 9 * 3)\end{array}$ & & $8 \%$ & \\
\hline & $\begin{array}{l}\text { Decreased CYP4F2 activity } \\
\quad(C Y P 4 F 2 * 3)\end{array}$ & $\begin{array}{l}\text { Increased levels of vitamin } \mathrm{K} \text { dihydroquinone, which } \\
\text { is necessary for carboxylation of coagulation factors }\end{array}$ & $1.1 \%$ & \\
\hline & $\begin{array}{l}\text { Reduced VKORC1 } \\
\text { activity }(\text { VKORC1*2) }\end{array}$ & $\begin{array}{l}\text { Reduced levels of vitamin } \mathrm{K} \text { dihydroquinone, which } \\
\text { is necessary for carboxylation of coagulation factors }\end{array}$ & $28.3 \%$ & \\
\hline Clopidogrel & $\begin{array}{l}\text { Reduced CYP2C19 } \\
\text { activity }(\text { CYP2C19*2) }\end{array}$ & Reduced bioactivation of the prodrug & $12 \%$ & {$[44]$} \\
\hline $\begin{array}{l}\text { Proton pump } \\
\text { inhibitors }\end{array}$ & $\begin{array}{l}\text { Increased CYP2C19 } \\
\text { activity }(\text { CYP2C19*17) }\end{array}$ & $\begin{array}{l}\text { Increased inactivation to } 5 \text {-hydroxyomeprazole in } \\
H . \text { pylori eradication therapy }\end{array}$ & $\begin{array}{l}\text { Eradication } 72.7 \% \text { in } \\
\text { UM and } 97.8 \% \text { in PM }\end{array}$ & [45] \\
\hline Atorvastatin & $\begin{array}{l}\angle P A(\mathrm{rs} 10455872) ; A P O E \\
\quad(\mathrm{rs} 445925, \mathrm{rs} 4420638)\end{array}$ & Decreased reduction in low-density lipoprotein cholesterol & $4 \%$ combined & [46] \\
\hline
\end{tabular}

$P M$ poor metabolizer, $U M$ ultrarapid metabolizer

the VKORC1 subunit of epoxide reductase, thereby disrupting the formation of the vitamin K-dependent clotting factors. Warfarin is a racemic mixture of $R$ - and $S$-enantiomers with the latter being around 5 times more potent. $S$-warfarin is inactivated by CYP2C9 and eliminated predominantly via the urine.

Genetic variants in $V K O R C 1$ and $C Y P 2 C 9$ have been reproducibly linked to differences in warfarin dose requirements. Reduced functionality polymorphisms in VKORC1 (mostly VKORC1*2) and CYP2C9 (particularly CYP2C9*2 and *3) have been associated with lower (1-2 mg/day reduction per allele) warfarin dose requirements [54-57]. In addition, the reduced functionality variant rs2108622 in the CYP4F2 gene whose gene product metabolizes vitamin $\mathrm{K}$ shows an additional minor contribution [43].

While the molecular mechanisms behind warfarin pharmacogenetics have been extensively analyzed, the advantages of preemptive genetic testing remain unclear and randomized, multi-center, controlled trials reported discrepant results. While the CoumaGen-II and EU-PACT trials indicated significant improvements in the percentage of time within the therapeutic international normalized ratio (INR) range and time to reach therapeutic INR with genotype-guided dosing $[58,59]$, the COAG trial did not show significant differences in the time within the therapeutic range or the incidence of bleeding complications [60]. Likely reasons for the mixed outcomes include differences in reference (usual care in EUPACT vs. dosing algorithm guided by clinical variables in COAG), the use of loading dose (loading dose given in EUPACT vs. no loading dose in COAG) or the diversity of the trial population (homogeneous European population in EUPACT vs. $27 \%$ Africans and 6\% Hispanics in COAG). Thus, while all trials suggest numerical, but not necessarily significant, benefits of genotype-guided dosing, the clinical utility of preemptive warfarin genotyping appears limited.

\section{The Role of $H L A$-Alleles in Hypersensitivity to Abacavir}

The antiretroviral guanoside analogue abacavir is commonly used for the treatment of HIV infections in adults and pediatric patients older than 3 months. While the drug is generally well tolerated, around $4 \%$ of patients experience hypersensitivity syndrome (HSS) that manifest as fever and gastrointestinal and respiratory problems as well as dermatological symptoms that range from rashes to Stevens-Johnson syndrome or toxic epidermal necrolysis [61]. Prospective, randomized clinical trials demonstrated that HSS is strongly associated with the presence of the $H L A-B * 57: 01$ allele with a negative predictive value of $100 \%$ and a positive predictive value of $47.9 \%$ [62]. Mechanistically, HSS is caused by activated abacavir-specific $\mathrm{CD}^{+}$T cells that are triggered by the abacavir parent molecule bound to $H L A-B * 57: 01$ [63]. This non-covalent binding is highly specific and can be abrogated by a single point mutation of the S116 residue, which results in a lack of T cell activation [64]. Following identification and clinical implementation of this pharmacogenomic biomarker, abacavir prescriptions drastically increased and indeed this biomarker might be one of the best examples where genotyping for one mutation can completely prevent the occurrence of compound toxicity. Prior to initiating abacavir therapy, screening for the $H L A$ $B * 5701$ allele is recommended by the FDA, the Clinical Pharmacogenetics Implementation Consortium (CPIC), and the Dutch Pharmacogenetics Working Group (DPWG) and in case the allele is detected, alternative therapy is mandated [65, $66]$.

\section{Associations Between TPMT Genotype and Thiopurine Toxicity}

The thiopurine mercaptopurine (6-MP) and its prodrug azathioprine (AZA) are used for the treatment of acute lymphoblastic leukemia (ALL) and are also widely prescribed off-label for their immunosuppressive effects in the treatment of Crohn's disease and ulcerative colitis. AZA is rapidly metabolized into 6-MP in the liver, which is further either bioactivated by hypoxanthine-guanine-phosphoribosyltransferase (HPRT) to form thioguanine nucleotides or inactivated by either thiopurine- $S$-methyltransferase (TPMT) or xanthine oxidase (XO) to 6-methylmercaptopurine or thiouric acid, respectively. 


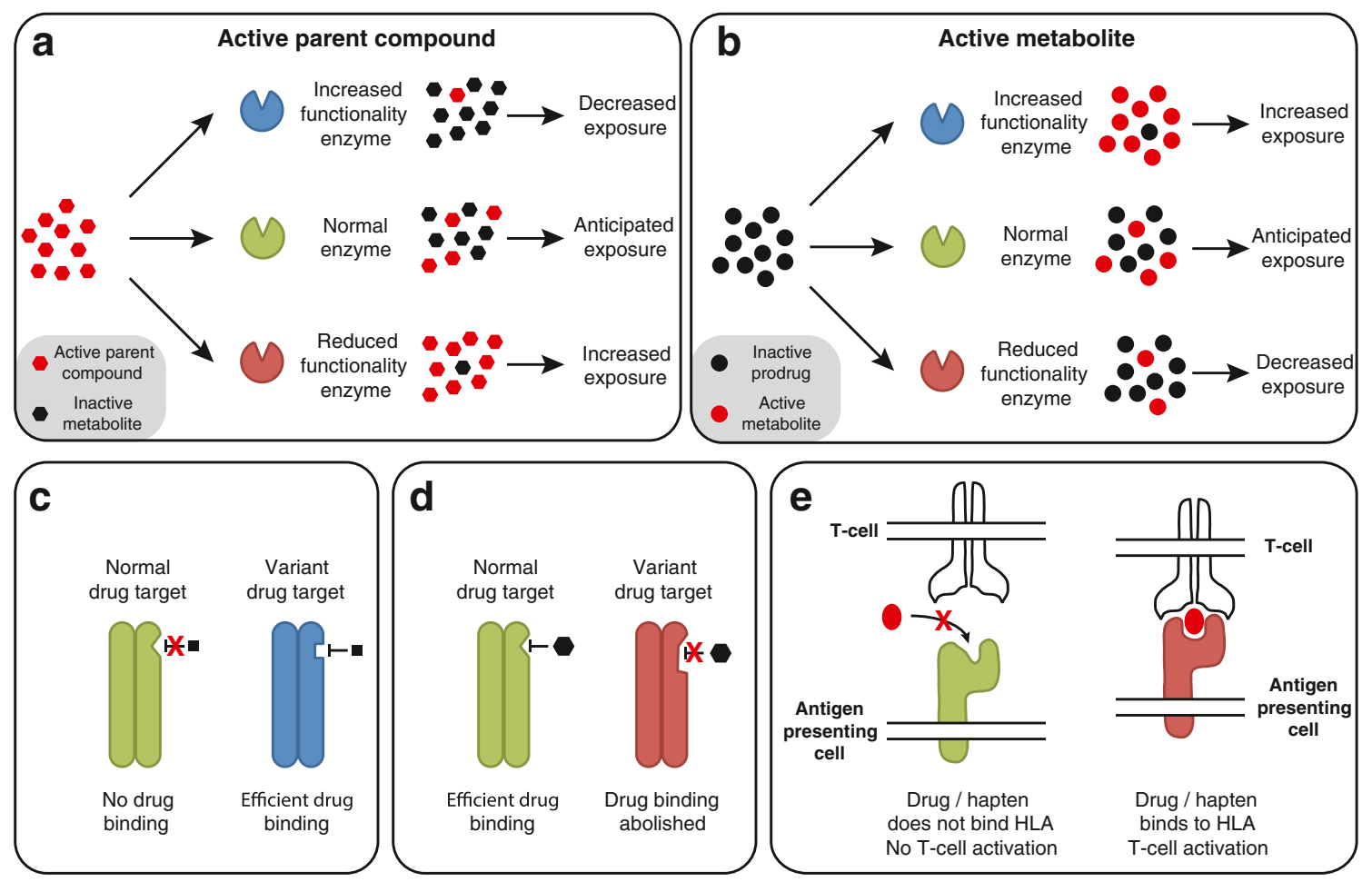

Fig. 1. Possible effects of genetic variations in pharmacogenes. Mutations in ADME genes can impact drug exposure. a In case of a pharmacologically active parent compound (red hexagons), increased functionality alleles can result in decreased drug exposure and reduced efficacy due to increased inactivation to inactive metabolites (black hexagons). One clinically relevant example is the increased metabolic inactivation of omeprazole in patients with the increased functionality allele CYP2C19*17 during Helicobacter pylori eradication therapy. In contrast, alleles with reduced functionality result in lower clearance and higher exposure, as exemplified by increased number of bleeding complications due to standard warfarin doses in patients with deficient CYP2C9 enzyme. b Conversely, when the administered compound is a prodrug (black circles), alleles with increased functionality results in elevated formation of active metabolites (red circles), higher exposure, and potentially toxicity. One prominent case of this class is morphine intoxication upon codeine treatment in patients with multiplicated active alleles of $C Y P 2 D 6$. Reduced metabolic activation of a prodrug generally results in lack of efficacy. Examples are the lack of analgesia due to codeine treatment in CYP2D6 poor metabolizers or treatment failure of clopidogrel in patients with reduced CYP2C19 activity. c Multiple drugs only bind to specific variant forms of the respective target protein, particularly in oncology (see Table 5). d During oncological treatment, drug targets frequently mutate entailing a lack of response to formerly very potent drugs. e Some drugs, such as abacavir and flucloxacillin, elicit immunemediated toxicity reactions by binding to specific variants of the major histocompatibility complex either directly or conjugated to a protein carrier as a hapten, which in turn facilitates activation of $\mathrm{T}$ cells and triggers an immune response

Myelosuppression is the most common adverse reaction to thiopurine therapy and patients with reduced TPMT activity are at substantially increased risk. Importantly, TPMT genotype is a strong predictor for TPMT activity and even patients heterozygous for the TPMT loss-of-function alleles $* 2 \mathrm{~A}$ or $* 3$ showed significantly higher incidences of dose reductions due to toxicity $[67,68]$. Due to the substantial body of evidence that links TPMT genotype to thiopurine treatment outcomes and adverse events, TPMT genotyping is already widely applied in clinical practice $[69,70]$. The costeffectiveness of preemptive TPMT genotyping remains however inconclusive [71, 72] and data from randomized controlled trials is currently lacking.

\section{The Role of SLCO1B1 Variants in Simvastatin-Induced Myopathy}

Severe toxicity has been observed in patients receiving the blockbuster drug simvastatin for treatment of dyslipidemia, an inhibitor of 3-hydroxy-3-methylglutaryl coenzyme A
(HMG-CoA) reductase, the rate-limiting enzyme of cholesterol biosynthesis. Importantly, the SNP rs4149056 located in SLCO1B1 (SLCO1B1*5), the gene encoding the hepatic simvastatin transporter OATP1B1, causes impaired hepatic import of the drug which prevents the interaction with its hepatic target HMG-CoA reductase and results in increased plasma concentration due to impaired hepatic clearance. Patients are at 2.6- or 4.5-fold increased risk per variant allele of developing myopathy when taking normal (40 mg daily) or high doses ( $80 \mathrm{mg}$ daily) of simvastatin, respectively [31]. Due to these risks, particularly in the high dose group, the FDA issued a warning that high dose regimens of simvastatin should only be used in patients who have already received high doses for more than 12 months without musclerelated adverse effects [73].

\section{DPYD Variants and Fluoropyrimidine Toxicity}

Combinatorial therapies that include fluorouracil, such as the chemotherapeutic regimens FOLFOX and FOLFIRI 
represent the first-line treatment for various solid tumors. Fluorouracil (5FU) and other fluoropyrimidines, such as capecitabine, tegafur, and floxuridine, inhibit thymidylate synthase, which catalyzes the rate-limiting step in deoxythymidine triphosphate (dTTP) biosynthesis, thereby inhibiting DNA replication [74]. Fluoropyrimidines have a narrow therapeutic window and dose-adjustments based on therapeutic drug monitoring (TDM) resulted in increased response-rate and decreased toxicity [75]. Dihydropyrimidine dehydrogenase (DPD), the enzyme encoded by DPYD, inactivates around $80 \%$ of $5 \mathrm{FU}$ and genetic polymorphisms in $D P Y D$ have been consistently linked to inter-individual differences in fluoropyrimidine response and toxicity [25, 76]. Importantly, a recent study in 2038 patients demonstrated that $5 \mathrm{FU}$ dosing guided by prospective genotyping for the reduced functionality allele $D P Y D * 2 A$ resulted in significantly lower incidences of severe toxicities $(73 \%$ in historic controls vs. $28 \%$ in genotype-guided cohort) and appeared to reduce costs for the health care system [77]. Thus, implementation of $D P Y D$ genotyping for 5FU therapy in routine clinical care might be a promising next step in reducing patient morbidity while at the same time allocating health care resources more efficiently.

\section{RARE GENETIC VARIANTS AND POPULATION- SPECIFICITY}

Genetic variants can be classified as common ( $>1 \%$ allele frequency, also called genetic polymorphisms) or rare ( $<1 \%$ frequency) depending on their prevalence in the overall population. Recent twin studies indicated that the contribution of genetic factors to drug response differs drastically between medications. While genetic factors contributed only to a minor extent to differences in talinolol pharmacokinetics, heritable factors were responsible for 80 $90 \%$ of the differences in the pharmacokinetics of metoprolol and torsemide; importantly, however, the analyzed common genetic polymorphisms only explained around $40 \%$ of this variability [78, 79]. These results indicate that additional factors, such as rare genetic variants can be important modulators of drug pharmacokinetics. Indeed, recent population-scale sequencing projects revealed that ADME genes harbor vast numbers of rare genetic variants that are not assessed by conventional genotyping arrays [80, 81]. Rare variants are more likely to have deleterious effects with an estimated odds ratio of 4.2 compared to variants with MAF > $0.5 \%[82,83]$ and combined are estimated to account for 30 $40 \%$ of the functional variability in ADME genes [81].

Importantly, variant and haplotype frequencies differ majorly between populations (Table 4). Thus, while a variant may be rare globally, frequencies of a minor allele might be substantial in specific populations. One such example is the prevalence of the reduced functionality allele $C Y P 2 C 8^{*} 2$, which is not found in individuals of European or East Asian ancestry but is common in Africans (MAF $=15.9 \%$ ) [7]. Similarly, the loss-of-function $C Y P 3 A 4^{*} 20$ allele causing increased risk of adverse reactions to, e.g., paclitaxel, was not found in Asian, African, South American, and most European populations but reached frequencies of $3.8 \%$ in specific regions of Spain [86]. Combined, these findings suggest that ethnic origin is an important parameter in pharmacogenomic research and understanding of the geographical distribution of genetic variability builds the fundament for precision public health approaches.

The treatment with antiretrovirals in Zimbabwe provides an impressive case for the benefit of such approaches: When the national ministry of health implemented a WHO recommendation to change the first-line treatment of HIV to efavirenz, unexpectedly many Zimbabweans experienced ADRs associated with efavirenz overdose. Importantly, in Zimbabwe, $20 \%$ of the population are homozygous for the reduced functionality allele $C Y P 2 B 6^{*} 6$ which entails that efavirenz plasma concentrations exceed the recommended therapeutic levels, resulting in the local failure of a globally established dosing regimen [87]. Thus, in order to prevent such public health crises, selection of first-line treatment should be evaluated for each population separately, considering the specific genetic landscapes in the geographic region of interest $[88,89]$.

\section{RARE VARIANTS AND PRECISION MEDICINE}

With decreasing sequencing times and costs, it is envisioned that precision medicine will increasingly utilize NGS technologies to derive predictions of drug response. Such analyses should be tailored to the drug in question and encompass genes likely to affect its kinetics, response, or risk of adverse reactions. In this concept, a pre-defined panel of genes is sequenced using NGS and genetic variants in the patient of interest are identified (Fig. 2). Analysis of the sequencing results will yield (i) non-sense mutations, such as frameshift, stop-gain, or start-lost variants; (ii) silent (also called synonymous) mutations; and (iii) missense mutations that result in amino acid exchanges. While exceptions from the rule exist, synonymous variants rarely have a functional effect, whereas the vast majority of non-sense variants result in a loss-of-function of the gene product. Missense variants however are more heterogenous: while some variants result in reduced functionality alleles, others do not have any functional effects. Overall, around $70 \%$ of genetic variants within coding sequences have no pronounced effect on the functionality of the gene product, whereas $30 \%$ of the mutations unveiled by exome sequencing result in reduced function or loss-of-function alleles.

Due to the vast number of rare genetic variants, it is not feasible to experimentally characterize the functional effects of all such mutations, thus posing a significant challenge for the clinical interpretation of genetic variability and hampering the translation of genomic data into actionable advice. In the absence of experimental data, in silico algorithms can provide some guidance regarding the predicted functional consequences of the genetic variant [90]. Ideally, the results of multiple such computational methods are integrated that base their conclusions on diverse and complementing sets of criteria, including evolutionary conservation, physiochemical properties, secondary structure, variant effects on protein stability, and protein domain information [91]. The predictive power of algorithms to detect functional alterations in the gene product is however relatively low, particularly in ADME genes. Current computational tools have been trained on disease-causing genetic variants and use evolutionary constraints as the main parameter to predict functional effects of 
Table 4. Overview of Important Pharmacogenetic Variant and Allele Frequencies Across Major Human Population

\begin{tabular}{|c|c|c|c|c|c|c|c|c|}
\hline \multirow[b]{2}{*}{ Allele } & \multirow[b]{2}{*}{ Defining variants } & \multirow[b]{2}{*}{ Variant type } & \multicolumn{5}{|c|}{$\begin{array}{l}\text { Allele frequencies in indicated populations (in } \\
\%)\end{array}$} & \multirow[b]{2}{*}{$\begin{array}{l}\text { Functional } \\
\text { consequence }\end{array}$} \\
\hline & & & EUR & AFR & EAS & SAS & AMR & \\
\hline$C Y P 2 B 6^{*} 6$ & rs2279343, rs3745274 & Missense (K262R, Q172H) & 3.4 & 5.8 & 2.7 & 15.8 & 3 & Decreased \\
\hline CYP2B6*16 & rs2279343 and rs28399499 & Missense (I328T) & 0 & 6.5 & 0 & $<0.1$ & 0.3 & Decreased \\
\hline$C Y P 2 C 8 * 2$ & rs11572103 & Missense (I269F) & 0 & 15.9 & 0 & 1.9 & 0.9 & Decreased \\
\hline$C Y P 2 C 8^{*} 3$ & rs10509681, rs11572080 & Missense (K399R, R139K) & 11.2 & 2.1 & $<0.1$ & 4 & 6.7 & Decreased \\
\hline$C Y P 2 C 8^{*} 4$ & rs1058930 & Missense (I264M) & 6.0 & 1.1 & 0 & 1.5 & 2.3 & Decreased \\
\hline$C Y P 2 C 9 * 2$ & rs1799853 & Missense (R144C) & 11.7 & 2.4 & $<0.1$ & 4.6 & 6.6 & Inactive \\
\hline$C Y P 2 C 9 * 3$ & rs1057910 & Missense (I359L) & 5.6 & 1.3 & 3.4 & 11.3 & 3.6 & Decreased \\
\hline$C Y P 2 C 9 * 8$ & rs7900194 & Missense (R150H) & 0 & 5.6 & $<0.1$ & $<0.1$ & 0.2 & Decreased \\
\hline$C Y P 2 C 9 * 11$ & rs 28371685 & Missense (R335W) & 0.5 & 2.1 & $<0.1$ & 0.2 & 0.2 & Decreased \\
\hline$C Y P 2 C 19 * 2$ & rs4244285 & Splicing defect & 18.3 & 18.1 & 31.0 & 34.0 & 10.1 & Inactive \\
\hline$C Y P 2 C 19 * 3$ & rs4986893 & Stop-gain (W212X) & $<0.1$ & $<0.1$ & 6.7 & 0.4 & $<0.1$ & Inactive \\
\hline$C Y P 2 C 19 * 17$ & rs12248560 & Regulatory & 22.4 & 23.5 & 1.5 & 13.6 & 12.0 & Increased \\
\hline$C Y P 2 D 6 * 1 x N$ & \multicolumn{2}{|c|}{ Amplification of $C Y P 2 D 6^{*} 1$} & 1 & 3.3 & 1 & 0.5 & 0.5 & Increased \\
\hline$C Y P 2 D 6 * 2 x N$ & \multicolumn{2}{|l|}{ Amplification of $C Y P 2 D 6 * 2$} & 1.3 & 6 & 1 & 1 & 0.5 & Increased \\
\hline$C Y P 2 D 6 * 3$ & rs 35742686 & Frameshift & 4.1 & 0.3 & 0 & 0.1 & 0.3 & Inactive \\
\hline$C Y P 2 D 6^{* 4}$ & rs3892097 & Splicing defect & 15.5 & 11.9 & 0.4 & 11.6 & 15.7 & Inactive \\
\hline$C Y P 2 D 6 * 5$ & CYP2D6 deleted & & 3 & 4 & 6.5 & 2 & 3 & Inactive \\
\hline$C Y P 2 D 6^{*} 6$ & rs5030655 & Frameshift & 2.2 & 0.3 & 0 & 0.1 & 0.4 & Inactive \\
\hline$C Y P 2 D 6 * 29$ & $\begin{array}{l}\text { rs } 16947, \text { rs } 1135840 \\
\quad \text { rs61736512, rs59421388 }\end{array}$ & $\begin{array}{l}\text { Missense (R296C, S486 T, } \\
\text { V136I, V338M) }\end{array}$ & 0 & 9.2 & $<0.1$ & $<0.1$ & $<0.1$ & Decreased \\
\hline CYP $3 A 5 * 3$ & rs 776746 & Splicing defect & 94.3 & 18.0 & 71.3 & 66.8 & 79.7 & Inactive \\
\hline CYP $3 A 5^{*} 6$ & rs10264272 & Splicing defect & 0.3 & 15.4 & 0 & 0 & 2.3 & Inactive \\
\hline$D P Y D * 2 A$ & rs3918290 & Splicing defect & 0.6 & $<0.1$ & 0 & 0.5 & $<0.1$ & Inactive \\
\hline$D P Y D * 13$ & rs55886062 & Missense (I560S) & $<0.1$ & 0 & 0 & 0 & 0 & Inactive \\
\hline$D P Y D$ & rs67376798 & Missense (D949V) & 0.4 & $<0.1$ & 0 & $<0.1$ & 0.2 & Inactive \\
\hline$S L C O 1 B 1 * 5$ & rs4149056 & Missense (V174A) & 16 & 2.8 & 12.6 & 5 & 10.6 & Decreased \\
\hline$T P M T * 2$ & rs1800462 & Missense (A80P) & 0.2 & $<0.1$ & 0 & 0 & 0.2 & Strongly decreased \\
\hline$T P M T^{*} 3 A$ & rs 1142345, rs 1800460 & Missense (A154T, Y240C) & 2.9 & 0 & 0 & 0 & 4 & Inactive \\
\hline$T P M T * 3 C$ & rs1142345 & Missense (Y240C) & 0 & 6.4 & 2.2 & 1.3 & 1.7 & Decreased \\
\hline$U G T 1 A 1 * 28$ & rs8175347 & Regulatory & 38.7 & 42.6 & 16 & 12.2 & 40 & Decreased \\
\hline
\end{tabular}

Data for $C Y P$ alleles is obtained from ref. [7]. Non- $C Y P$ variants with pharmacogenetic importance in $S L C O 1 B 1, T P M T$, or $D P Y D$ were obtained from ExAC [84] or the 1000 Genomes project [85]

EUR Europeans, AFR Africans, EAS East Asians, SAS South Asians, $A M R$ ad mixed Americans

the mutations in question. Such an approach poses problems for the assessment of pharmacogenetic variants as ADME genes are often only poorly conserved. Consequently, while computational tools correctly classify disease-causing variants with accuracies between 70 and 90\% [92-95], a comprehensive assessment of their performance for ADME missense variants revealed only much lower predictive accuracies. ADME-specific optimization of computational prediction models is thus necessary, which will provide an important step forward to allow the rapid translation of exome sequencing data into a compendium of functionally altered genes of relevance for the specific drug therapy in question for each patient, adding relevant information for pharmacogenetically guided drug therapy.

There is evidently a need to improve both in silico and experimental methods for functional prediction of missense mutations. However, already today NGS-based approaches provide more accurate and more individualized information for pharmacogenomic predictions of drug action than the current array based techniques that focus solely on common genetic variants. To facilitate the translation of this perception into clinically actionable information and to fully harness the added value of clinical NGS, overcoming the indicated limitations thus constitutes one of the most important frontiers of future pharmacogenomic research.

\section{GENETIC BIOMARKERS IN THE SOMATIC CANCER GENOME}

Currently, cancer affects around 90 million individuals and causes nearly 1 in 6 deaths worldwide [96]. Underlying the formation of neoplasms is the accumulation of somatic mutations that activate the so-called oncogenes and inactivate tumor suppressors. Every tumor harbors a unique combination of acquired genetic variants and cancer genomics, i.e., the analysis of genetic differences between tumor and non-tumor cells aims to unveil the genetic basis that confers cancer cells their proliferative capacity and the ability to escape apoptosis. By revealing its molecular underpinnings and identifying clinically actionable variants that can be targeted by approved 


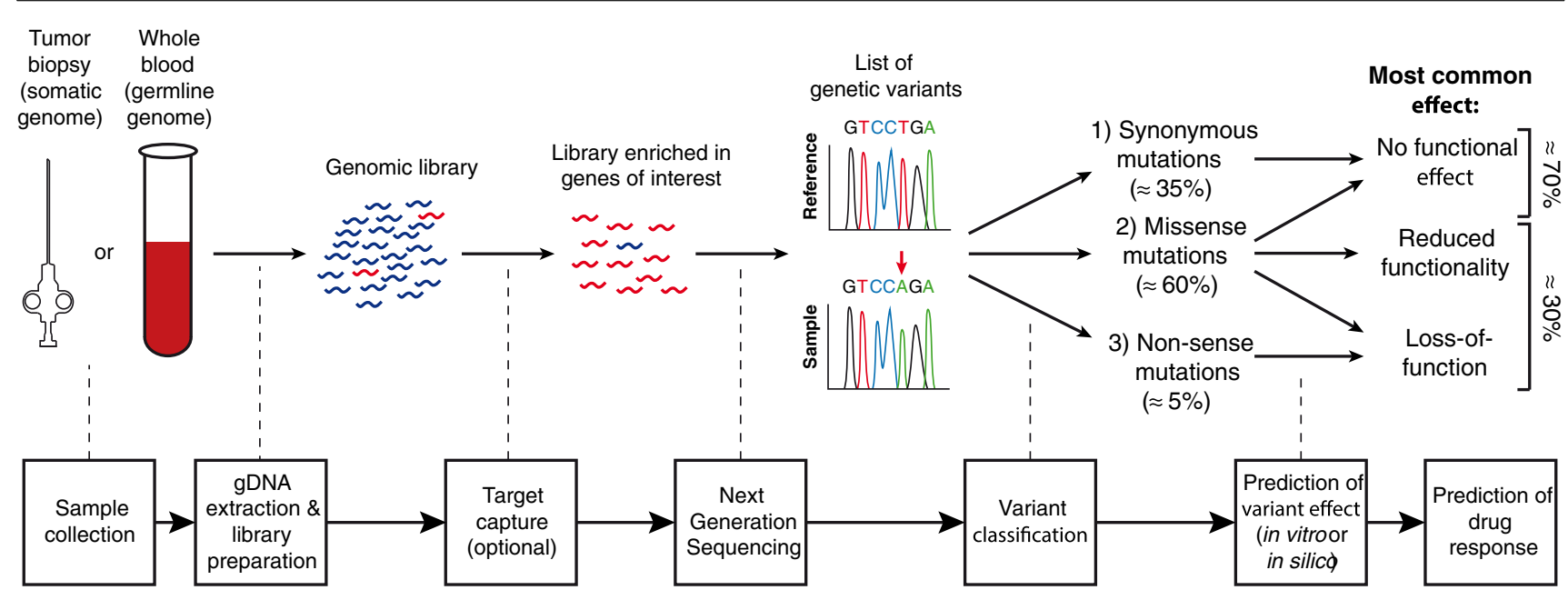

Fig. 2. The use of next-generation sequencing in precision medicine. Genomic DNA (gDNA) is isolated from tissue biopsies (somatic genome) or from blood samples (germline genome) and libraries for downstream sequencing applications are prepared. Optionally, a target capture step can be performed to enrich for genomic intervals of interest and to reduce required sequencing capacity. Subsequent to sequencing, genetic variants in the sample (indicated by red arrow) are identified by comparison to a relevant reference, which can be either the human reference genome or, in the case of tumor biopsies, the germline genome from the same patient. The functional consequence of identified variants can be predicted based on preexisting experimental data or if such information is not available by using computational algorithms

drugs, this approach allows to tailor therapy to the specific tumor, opening new avenues for personalized oncology (Table 5).

To date, the most commonly identified oncogenic variants affect signal transduction systems, cell cycle genes, metabolic enzymes, the epigenetic machinery, or factors involved in transcription, splicing, or translation (Fig. 3). Prominent examples of such mutations result in the constitutive activation of growth factor signaling. Approved targeted therapies are available for variants in receptor tyrosine kinases, such as EGFR (also termed HER1), ERBB2 (also termed HER2), $P D G F R A, K I T, A L K$, and $J A K 2$ that are commonly mutated in various cancers. Furthermore, targeting activating mutations, amplifications, or gene fusion events of FGFRs represents promising therapeutic opportunities for various solid tumors with multiple clinical trials currently ongoing [104].

Depending on the cancer type and nature of these polymorphisms, the use of targeted therapies is indicated that interfere with specific mutated gene products found exclusively in cancer cells. For instance, treatment with the EGFR inhibitors afatinib, erlotinib, and gefitinib improves progression-free survival of non-small cell lung cancer (NSCLC) patients that harbor deletions in exon 19 of EGFR or $\mathrm{EGFR}^{\mathrm{L} 858 \mathrm{R}}$ substitution mutations [105-107]. In contrast, EGFR inhibition did not result in improved clinical outcomes in glioblastoma patients compared to conventional chemo- and radiation therapy [108]. However, even in patients that are initially responsive to targeted therapy, drug resistance can arise most commonly due to the acquisition of additional mutations. In NSCLC patients, the $\mathrm{EGFR}^{\mathrm{T} 790 \mathrm{M}}$ variant decreases the affinity of tyrosine kinase inhibitors (TKIs) to bind to the ATP binding pocket of EGFR and represents the most common mechanism of EGFR inhibitor resistance [109]. To counter this acquired drug resistance, the FDA-approved osimertinib, which demonstrated significantly increased efficacy in T790M-positive NSCLC patients compared to conventional platinum-based therapy [110].

In addition to point mutations, cancer cells often undergo genomic rearrangements that can result in the deletion of entire exons or the formation of functional fusion proteins. Chronic myeloid leukemia (CML) is characterized by a specific genomic translocation event between chromosomes 9 and 22 that gives rise to a functional BCR-ABL1 fusion protein that exhibits constitutive kinase activity. The TKI imatinib inhibits the phosphorylation of downstream targets of BCR-ABL1 and in addition blocks various other kinases, such as PDGFRA and KIT. While response rates to imatinib are very high (hematologic remission in $97 \%$ of CML patients), $51-88 \%$ of late stage patients developed imatinib resistance $[111,112]$. Mechanisms of imatinib resistance include point mutations in BCR-ABL1, amplifications of the chimeric gene as well as BCR-ABL1-independent mechanisms, such as overexpression of efflux transporters or downregulation of the imatinib importer OCT1 [113]. By now, a variety of therapeutic options is available for the treatment of imatinib-resistant CML. Nilotinib and dasatinib are effective against most imatinib-resistant point mutants with the exception of cells with the T315I mutation [114]. For BCR-ABL1 $1^{\mathrm{T} 315 \mathrm{I}}$-positive CML, the recently approved TKI ponatinib (full FDA approval in 2016) demonstrated a major cytogenetic response in $56 \%$ of patients irrespective of BCRABL1 mutation status and thus significantly improves clinical outcomes for the respective patients [115].

The examples provided above give an impression of the complexity of genetic variability in cancer cells. Due to increasing throughput and decreasing costs of sequencing, genetic information of primary cancers as well as metastases becomes progressively more available. This massive amount of data can be accessed at central data hubs, such as the Genomic Data Commons (GDC; https://gdc.cancer.gov/) provided by the National Cancer Institute that currently provides genomic information of 14,551 cases and the Catalog Of Somatic Mutations In Cancer (COSMIC; http://cancer.sanger.ac.uk/cosmic) hosted by the Sanger Institute, which constitutes the largest database of somatic cancer mutations. However, the translation of this unveiled landscape of oncogenetic variability into clinical advice remains difficult despite the multitude of computational 
Table 5. Approved Targeted Cancer Drugs

\begin{tabular}{|c|c|c|c|}
\hline Drug family & Drug & Indication & Biomarker \\
\hline $\begin{array}{l}\text { ERBB2 inhibitor } \\
\text { ERBB2 mAb }\end{array}$ & $\begin{array}{l}\text { Lapatinib } \\
\text { Pertuzimab } \\
\text { Trastuzumab }\end{array}$ & BRCA & ERBB2 overexpression \\
\hline EGFR inhibitor & $\begin{array}{l}\text { Erlotinib } \\
\text { Gefitinib }\end{array}$ & $\begin{array}{l}\text { NSCLC } \\
\text { NSCLC, EC }\end{array}$ & $\begin{array}{l}\text { EGFR mutations except T790M, EGFR exon } 19 \text { deletions } \\
\text { Some EGFR mutations except T790M, EGFR exon } 19 \text { deletions, } \\
\text { EGFR amplification }\end{array}$ \\
\hline EGFR mAb & $\begin{array}{l}\text { Osimertınıb } \\
\text { Cetuximab }\end{array}$ & $\begin{array}{l}\text { NSCLC } \\
\text { CRC }\end{array}$ & $\begin{array}{l}\text { EGFR T790M mutation } \\
\text { EGFR overexpression }\end{array}$ \\
\hline $\begin{array}{l}\text { ERBB2 and EGFR } \\
\text { inhibitor }\end{array}$ & Afatinib & NSCLC & EGFR mutations, EGFR exon 19 deletions \\
\hline \multirow[t]{4}{*}{ BCR-ABL inhibitor } & $\begin{array}{l}\text { Bosutinib } \\
\text { Dasatinib }\end{array}$ & $\begin{array}{l}\text { CML } \\
\text { ALL, CML }\end{array}$ & BCR-ABL1 fusion, ABL1 mutations \\
\hline & Imatinib & $\begin{array}{l}\text { ALL, CML, GSC, MDS, } \\
\text { melanoma }\end{array}$ & $\begin{array}{l}\text { BCR-ABL1 fusion, PDGFRA fusion, PDGFRA mutation, KIT } \\
\text { mutations }\end{array}$ \\
\hline & Nilotinib & CML & BCR-ABL1 fusion, ABL1 mutations \\
\hline & Ponatinib & ALL, CML & BCR-ABL1 fusion, ABL1 T315I mutation \\
\hline BRAF inhibitor & $\begin{array}{l}\text { Dabrafenib } \\
\text { Vemurafenib }\end{array}$ & Melanoma & BRAF V600E mutation \\
\hline ALK inhibitor & $\begin{array}{l}\text { Ceritinib } \\
\text { Crizotinib }\end{array}$ & NSCLC & ALK fusion \\
\hline MTOR inhibitor & Everolimus & BRCA, GCA, RA & $\begin{array}{l}\text { ERBB2 expression and ESR1 overexpression, TSC1 or TSC2 } \\
\text { mutations }\end{array}$ \\
\hline PARP inhibitor & Olaparib & OVC & BRCA1 or BRCA2 mutations \\
\hline CDK4/6 inhibitor & Palbociclib & BRCA & ERBB2 expression and ESR1 overexpression \\
\hline Retinoid & Tretinoin & GC & PML-RARA fusion \\
\hline SHH inhibitor & Vismodegib & $\mathrm{BCC}, \mathrm{MB}$ & PTCH1 mutations \\
\hline JAK inhibitor & Ruxolitinib & Myelofibrosis & JAK2 V617F mutation \\
\hline MEK inhibitor & Trametinib & Melanoma & BRAF V600E or V600K mutations \\
\hline \multirow[t]{2}{*}{ Pan-TK inhibitor } & $\begin{array}{l}\text { Regorafenib } \\
\text { Sunitinib }\end{array}$ & GSC & KIT or PDGFRA mutations \\
\hline & Vandetanib & THC & RET mutations \\
\hline
\end{tabular}

$A M L$ acute lymphoblastic leukemia, $B C C$ basal cell carcinoma, $B R C A$ breast cancer, $C M L$ chronic myeloid leukemia, $C R C$ colorectal cancer, $E C$ endometrial cancer, $G C A$ giant cell astrocytoma, $G C$ gastric cancer, $G S C$ gastrointestinal stromal cancer, $M B$ medulloblastoma, $M D S$ myelodisplasic syndrome, $N S C L C$ non-small cell lung cancer, $O V C$ ovarian cancer, $R A$ renal angiomyolipoma, THC thyroid carcinoma

tools that assist in detection and interpretation of cancer genome alterations [116]. There is thus an urgent need for methods that support the identification of causative mutations that drive tumorigenesis and select alterations that may be therapeutically actionable. The recently launched Cancer Genome Interpreter (http://www.cancergenomeinterpreter.org) provides a versatile tool to estimate the biological significance of observed mutations and to predict their clinical relevance. However, prospective randomized trials of sufficient scale that demonstrate a clinical benefit of genomic profiling-guided off-label use for advanced cancer patients are still lacking [117].

The rapid progress in method development enabled the screening of hundreds of genes in the somatic and germline genome. Many platforms are by now commercially available and are increasingly used in clinical trials in which genomic DNA of different tumors is comprehensively analyzed using NGS for associations between genetic variability and therapeutic success of the anticancer therapy in question. Such an approach is mainly warranted for drugs for which the presence of mutations in genes encoding the signal transducers and modulators will determine the clinical success of the inhibitor in question, such as new antibodies that interfere in receptor-mediated signal transduction. We thus anticipate that pharmacogenetically guided anticancer therapy will increasingly utilize biomarkers consisting of a set of mutations in critical genes.

\section{EMERGING TECHNOLOGIES FACILITATING BIOMARKER DISCOVERY}

The knowledge we have gained about pharmacogenomic biomarkers, particularly regarding the importance of rare and population-specific variants, can be attributed to the increase in speed and accuracy of NGS technology, combined with decreasing prices. However, certain challenges of short-read sequencing remain and particularly the mapping of structural variants, copy number variations $(\mathrm{CNVs})$ and of large $(>1 \mathrm{~kb})$ repetitive elements remains problematic [118]. Filtering variants called using standard filters for short-read sequencing results in the removal of low complexity regions, segmental duplications and variable number tandem repeats. As a consequence, the pharmacogenetic variability in important genes, such as $C Y P 2 A 6, C Y P 2 B 6, C Y P 2 D 6, C Y P 3 A 4, G S T M 1, H L A-B$, $U G T 2 B 15$, and $U G T 2 B 17$ cannot be interrogated by standard paired-end 150 bp sequencing (Fig. 4). Similarly, a substantial proportion of variants cannot be called with high confidence for 


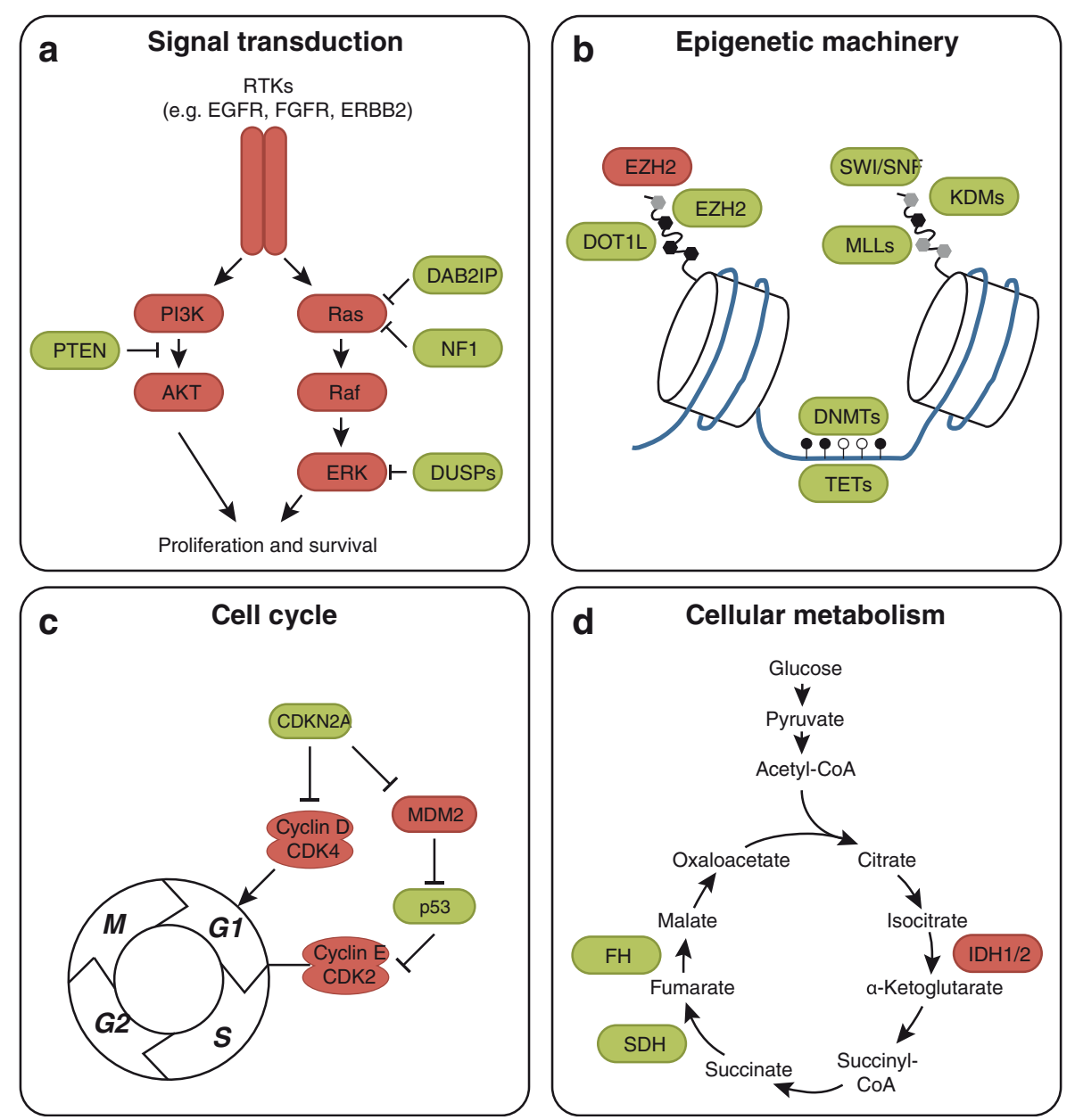

Fig. 3. Molecular pathways that commonly harbor oncogenic mutations. a Signal transduction cascades, such as the PI3K-AKT and Ras-ERK pathways, are commonly mutated in various cancers resulting in constitutive activation of signaling leading to cell survival and proliferation. $\mathbf{b}$ Components of the epigenetic machinery, such as DNA methyltransferases (DNMTs), histone modifying enzymes (DOT1L, MLLs, KDMs), and nucleosome remodelers are inactivated in up to $50 \%$ of ovarian or hepatocellular carcinomas [97, 98]. Interestingly, some cancers are also characterized by increased functionality of epigenetic enzymes, as exemplified by amplifications or increased catalytic activity mutations in the histone methyltransferase EZH2 in breast cancer and B cell lymphoma [99, 100]. c Similarly, multiple cancer types exhibit loss of cell cycle regulators or overexpression of cyclins or cyclin-dependent kinases (CDKs) [101, 102]. d Tumors are characterized by extensive metabolic remodeling. For instance, the R132H mutation in IDH1 modulates enzyme specificity and results in production of the oncometabolite 2-hydroxyglutarate, which inhibits DNA and histone modifying enzymes [103]. Oncogenes are indicated in red, tumor suppressors in green. RTK = receptor tyrosine kinase

genes containing repeats larger than 1 kilobase $(\mathrm{kb})$, including $A B C B 1, S L C 19 A 1$, and SLC22A1.

Long-read sequencing technologies aspire to enhance the recovery of reads that cannot be unambiguously mapped by short-read sequencing. In recent years, multiple long-read sequencing approaches have been presented (Fig. 5). Pacific Biosciences (PacBio) offers platforms for single-molecule real-time (SMRT) sequencing that have been successfully applied to medical genotyping as well as to the sequencing of human genomes [119-121]. The long reads allow for accurate variant calling as well as phasing of multiple heterozygous variants whose genomic location might be several kilobases apart. As such, SMRT provides an excellent technology for the sequencing of complex $C Y P$ loci and, using $C Y P 2 D 6$ as an example, has been demonstrated to allow the simultaneous detection of SNVs and CNVs in multiplexed samples [122, 123]. In addition to genomic sequencing, SMRT allows direct decoding of epigenetic marks [124].

Nanopore sequencing developed by Oxford Nanopore Technologies offers an alternative to the PacBio platform. Recent progress towards higher throughput, including whole genome sequencing (WGS), as well as detection of DNA methylation, also makes it well suited for biomarker discovery in complex regions of the genome [125, 126]. Furthermore, long-read sequencing combined with target capture methods based on the hybridization of biotinylated baits offers the possibility to focus on specific genomic regions of interest [127, 128]. A recent elegant approach demonstrated the utility of direct selection of DNA fragments in real-time by dynamic time warping and matching reads to the reference 


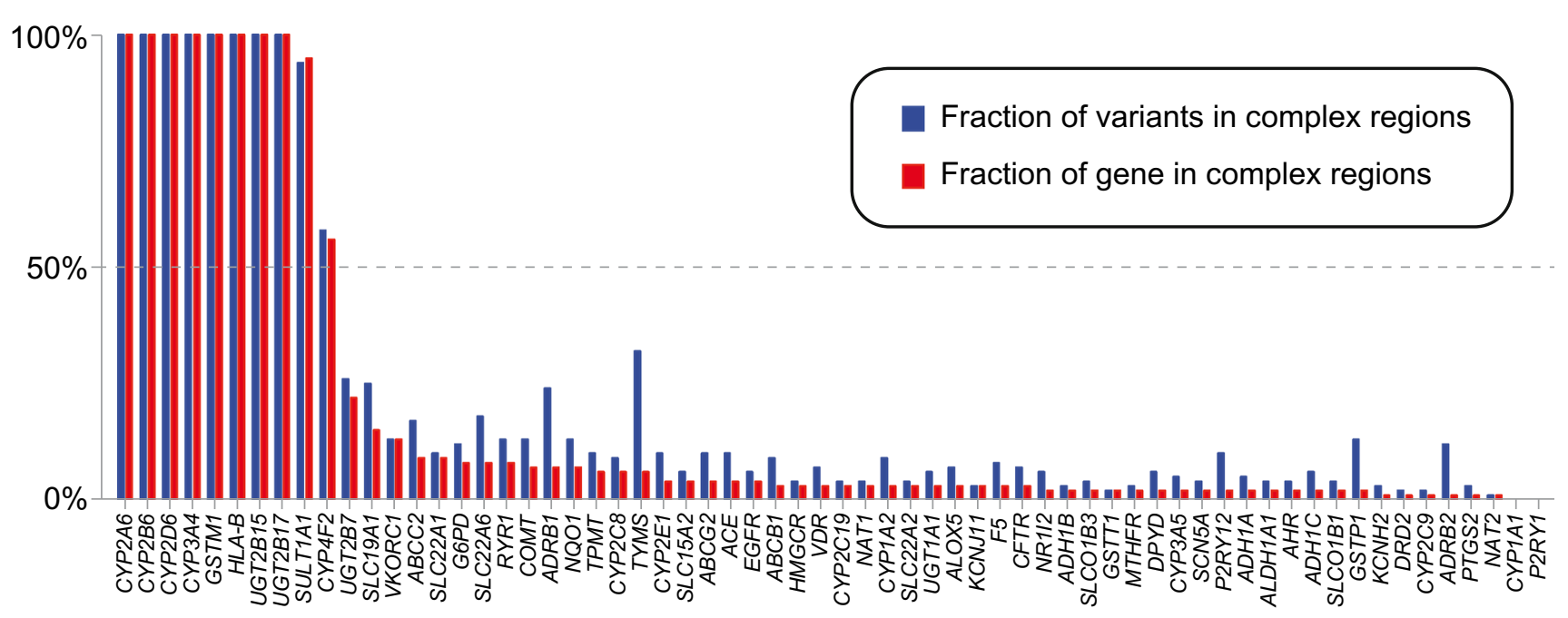

Fig. 4. Fraction of genomic intervals of major ADME genes in complex regions of the genome. The barplots illustrate the fraction of variants (blue) and base pairs (red) that lie low complexity regions of the genome or span segmental duplications or variable number tandem repeats. Importantly, these regions cannot be reliably interrogated by conventional short-read sequencing techniques

genome [129]. Thus, its portability, flexibility, and speed in data production make nanopore sequencing suitable for realtime applications, including direct point-of-care pharmacogenomic testing.

Besides long-read sequencing, various approaches to generate synthetic long-reads have been presented. The main advantage of synthetic methods is that they can leverage the low cost and high accuracy of short-read sequencing. Illumina's TruSeq Synthetic Long-Read technology, previously referred to as Moleculo, is based on fragmenting genomic DNA to approximately $10 \mathrm{~kb}$ fragments, their clonal amplification, shearing, and indexing with a unique barcode. Similarly, contiguity preserving transposase sequencing from Illumina provide in vitro means of generating libraries comprised of thousands of indexed pools, each containing thousands of sparsely sequenced long fragments, ranging from $5 \mathrm{~kb}$ up to 1 megabase [130]. The Chromium platform (10× Genomics) provides synthetic long reads by partitioning and barcoding the genome, followed by sequencing on any NGS platform. The barcoded linked reads can be aligned using "read clouds," thereby overcoming the complexities of mapping reads in repetitive regions of the genome. All linked reads for a single barcode are aligned simultaneously, with the prior knowledge that the reads arise from a small number of long (10-200 kb) molecules [131].

In summary, "real" as well as synthetic long-range sequencing represent promising emerging technologies that allow the phasing of variants, which can refine pharmacogenetic genotype calls and thus improve the phenotypic prediction regarding drug response. a

Short read sequencing (e.g. Illumina 2x150bp)

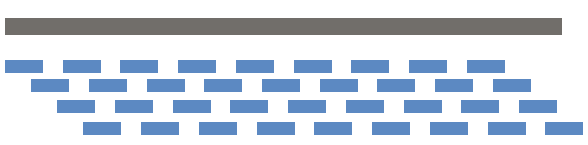

b

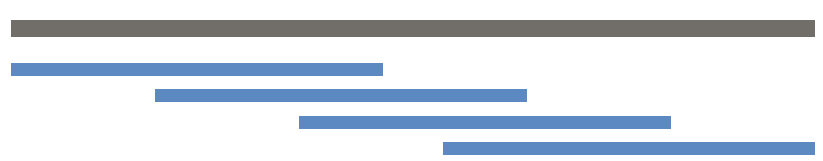

c Synthetic long reads sequencing (e.g. 10X Genomics)

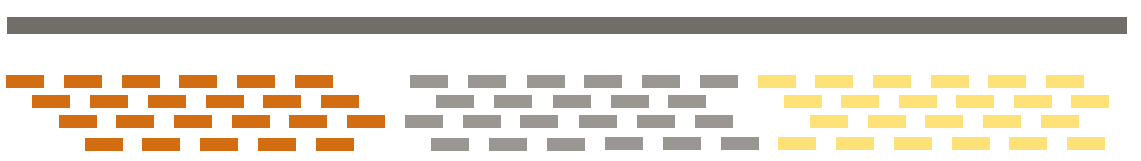
1. Partitioning, fragmenting
and barcoding

2. Short read sequencing

3. Assembly into $100 \mathrm{~kb}$

fragments and scaffolding

Fig. 5. Schematic depiction of next-generation sequencing paradigms. a Short-read sequencing requires the mechanic fragmentation of DNA into small 600-800-bp-long molecules, which are then sequenced from one or both ends and mapped to a reference genome using standard bioinformatics tools. b Pacific Biosciences (PacBio) and Oxford Nanopore Technologies allow sequencing of longer molecules which can ameliorate the obstacles of mapping short reads in repetitive or low complexity regions. c Synthetic long-read methods have been developed, which use partitioning and barcoding of longer DNA molecules before standard library preparation. This allows the assembly of short reads into longer fragments that can subsequently be mapped and scaffolded with efficiencies similar to those of physical long-read sequencing techniques 


\section{CLINICAL IMPLEMENTATION OF PHARMACOGENOMICS}

The clinical implementation of pharmacogenomic biomarkers is increasing and information about the importance of genetic variation has been included in the labels of 190 and 155 drugs approved by the US Food and Drug Administration (FDA) and the European Medicines Agency (EMA), respectively (https://www.fda.gov/Drugs/ScienceResearch/ ResearchAreas/Pharmacogenetics/ucm083378.htm) [132].

A central question is to what extent the preemptive use of pharmacogenomic biomarkers results in increased benefits for patients and society. So far, results of prospective randomized trials have been presented only for a very limited number of drugs [133]. In Europe, a large prospective trial called PREPARE (PREemptive pharmacogenomic testing for Preventing Adverse drug REactions) has been initiated by the EU-financed Ubiquitous Pharmacogenomics project (http://upgx.eu/) that aims to implement and evaluate the impact of pharmacogenomic testing on therapeutic outcomes in seven European clinical centers [134]. In total, 8100 patients will be enrolled and 40 clinically relevant PGx markers across 13 important pharmacogenes will be analyzed. In one arm of the trial, patients will receive treatment based on standard physiological and clinical parameters, whereas patients in the other arm will receive pharmacogenetically guided therapy. Outcomes of this interesting trial are expected in 2020.

In the USA, the NIH-funded eMERGE project has entered the final stage, which aims at analyzing the importance of rare genetic variants on patient phenotypes, developing technical and regulatory solutions to integrate genomic information into Electronic Health Records (EHR), assessing physician and patient attitudes towards the value of pharmacogenomic data, developing educational programs, and increasing the knowledge and awareness of clinically significant genetic variants. Additional programs conducted in the USA have been reviewed recently [135].

\section{POINTS TO CONSIDER FOR STUDIES OF CLINICAL PHARMACOGENOMICS}

Importantly, certain pitfalls should be considered when evaluating the clinical importance of pharmacogenomic associations. The problems include the analysis of populations that are heterogenous regarding ethnicity or disease classification, the inappropriate pooling of data derived from noncompatible studies, the use of inappropriate methods for isolation or sequencing of genomic DNA, use of somatic DNA instead of germline DNA, and vice versa, concluding on the basis of inaccurate proxy polymorphisms and erroneous haplotype identification based on a set of genetic variants. Furthermore, the choice of genotyping methodology, including appropriate selection of interrogated SNPs or genomic intervals as well as an assessment of the analytical validity of the chosen method, constitutes important aspects during the project planning phase. In case NGS-based approaches are used for genotyping, strategies should be in place to interpret encountered rare genetic variants with unknown functional consequences [136]. Thus, in order to assist the design and interpretation of studies of pharmacogenomic biomarkers, the EMA has released a draft guideline (http://
www.ema.europa.eu/docs/en_GB/document_library/ Scientific_guideline/2016/05/WC500205758.pdf).

\section{CONCLUSIONS}

Pharmacogenomic information provides an important tool for patient stratification and the selection of optimal drug and dosing regimens, particularly in oncology. However, in other therapeutic areas, the routine use of pharmacogenomic biomarkers in clinical practice is currently sparse primarily due to the lack of convincing data that show the added value for patient and health care providers. Importantly, the large prospective trials that are currently conducted in EU and the USA will shed light on the overall benefits of this technology and provide answers to how and where the implementation of preemptive pharmacogenomically guided drug treatment should be recommended.

\section{ACKNOWLEDGEMENTS}

The work in the authors' laboratories is supported by the European Union's Horizon 2020 research grants 668353 and 692145, the Swedish Research Council [grant agreement numbers: 2015-02760, 2016-01153, and 2016-01154], the Estonian Research Council [grant IUT20-60], and EU Project No. 2014-2020.4.01.15-0012.

\section{COMPLIANCE WITH ETHICAL STANDARDS}

Conflict of Interest The authors are not aware of any affiliations, memberships, funding, or financial holdings that might be perceived as affecting the objectivity of this review.

Open Access This article is distributed under the terms of the Creative Commons Attribution 4.0 International License (http://creativecommons.org/licenses/by/4.0/), which permits unrestricted use, distribution, and reproduction in any medium, provided you give appropriate credit to the original author(s) and the source, provide a link to the Creative Commons license, and indicate if changes were made.

\section{REFERENCES}

1. Krahenbuhl-Melcher A, Schlienger R, Lampert M, Haschke M, Drewe J, Krähenbühl S. Drug-related problems in hospitals-a review of the recent literature. Drug Saf. 2007;30(5):379-407. https://doi.org/10.2165/00002018-200730050-00003.

2. Tache SV, Soennichsen A, Ashcroft DM. Prevalence of adverse drug events in ambulatory care: a systematic review. Ann Pharmacother. 2011;45(7-8):977-89. https://doi.org/ 10.1345/aph.1P627.

3. Lauschke VM, Ingelman-Sundberg M. The importance of patientspecific factors for hepatic drug response and toxicity. Int J Mol Sci. 2016;17(10):1714. https://doi.org/10.3390/ijms17101714.

4. Sim SC, Kacevska M, Ingelman-Sundberg M. Pharmacogenomics of drug-metabolizing enzymes: a recent update on clinical implications and endogenous effects. Pharmacogenomics J. 2013;13(1):111. https://doi.org/10.1038/tpj.2012.45. 
5. Wienkers LC, Heath TG. Predicting in vivo drug interactions from in vitro drug discovery data. Nat Rev Drug Discov. 2005;4(10):825-33. https://doi.org/10.1038/nrd1851.

6. Evans WE, Relling MV. Pharmacogenomics: translating functional genomics into rational therapeutics. Science. 1999;286(5439):48791. https://doi.org/10.1126/science.286.5439.487.

7. Zhou Y, Ingelman-Sundberg M, Lauschke VM. Worldwide distribution of cytochrome P450 alleles: a meta-analysis of population-scale sequencing projects. Clin Pharmacol Ther. 2017;17(4 Pt 2):E1714-3. https://doi.org/10.1002/cpt.690.

8. Warton K, Mahon KL, Samimi G. Methylated circulating tumor DNA in blood: power in cancer prognosis and response. Endocr Relat Cancer. 2016;23(3):R157-R71. https://doi.org/ 10.1530/ERC-15-0369.

9. Lauschke VM, Ivanov M, Ingelman-Sundberg M. Pitfalls and opportunities for epigenomic analyses focused on disease diagnosis, prognosis, and therapy. Trends Pharmacol Sci. 2017;38(9):765-70. https://doi.org/10.1016/j.tips.2017.05.007.

10. Lauschke VM, Barragan I, Ingelman-Sundberg $\mathbf{M}$. Pharmacoepigenetics and toxicoepigenetics: novel mechanistic insights and therapeutic opportunities. Ann Rev Pharmacol Toxicol. 2017.

11. Costa-Pinheiro P, Montezuma D, Henrique R, Jerónimo C. Diagnostic and prognostic epigenetic biomarkers in cancer. Epigenomics. 2015;7(6):1003-15. https://doi.org/10.2217/ epi.15.56.

12. Ingelman-Sundberg M, Oscarson M, McLellan RA. Polymorphic human cytochrome P450 enzymes: an opportunity for individualized drug treatment. Trends Pharmacol Sci. 1999;20(8):342-9. https://doi.org/10.1016/S0165-6147(99)01363-2.

13. Danielson PB, MacIntyre RJ, Fogleman JC. Molecular cloning of a family of xenobiotic-inducible drosophilid cytochrome p450s: evidence for involvement in host-plant allelochemical resistance. Proc Natl Acad Sci. 1997;94(20):10797-802. https:// doi.org/10.1073/pnas.94.20.10797.

14. Daborn PJ, Yen JL, Bogwitz MR, Le Goff G, Feil E, Jeffers S, et al. A single p450 allele associated with insecticide resistance in Drosophila. Science. 2002;297(5590):2253-6. https://doi.org/ 10.1126/science. 1074170.

15. Karatolos N, Williamson MS, Denholm I, Gorman K, FfrenchConstant RH, Bass C. Over-expression of a cytochrome P450 is associated with resistance to pyriproxyfen in the greenhouse whitefly Trialeurodes vaporariorum. PLoS One. 2012;7(2):e31077-8. https://doi.org/10.1371/journal.pone.0031077.

16. Mao W, Schuler MA, Berenbaum MR. CYP9Q-mediated detoxification of acaricides in the honey bee (Apis mellifera). Proc Natl Acad Sci U S A. 2011;108(31):12657-62. https:// doi.org/10.1073/pnas.1109535108.

17. Zimmer CT, Bass C, Williamson MS, Kaussmann M, Wölfel K, Gutbrod O, et al. Molecular and functional characterization of CYP6BQ23, a cytochrome P450 conferring resistance to pyrethroids in European populations of pollen beetle, Meligethes aeneus. Insect Biochem Mol Biol. 2014;45(C):1829. https://doi.org/10.1016/j.ibmb.2013.11.008.

18. Bass C, Zimmer CT, Riveron JM, Wilding CS, Wondji CS, Kaussmann M, et al. Gene amplification and microsatellite polymorphism underlie a recent insect host shift. Proc Natl Acad Sci U S A. 2013;110(48):19460-5. https://doi.org/10.1073/ pnas. 1314122110.

19. Ingelman-Sundberg M. Genetic polymorphisms of cytochrome P450 2D6 (CYP2D6): clinical consequences, evolutionary aspects and functional diversity. Pharmacogenomics J. 2005;5(1):6-13. https://doi.org/10.1038/sj.tpj.6500285.

20. Meletis J, Konstantopoulos K. Favism-from the 'avoid fava beans' of Pythagoras to the present. HAEMA. 2004;7(1):1721.

21. Carr DF, la Porte CJL, Pirmohamed M, Owen A, Cortes CP. Haplotype structure of CYP2B6 and association with plasma efavirenz concentrations in a Chilean HIV cohort. J Antimicrob Chemother. 2010;65(9):1889-93. https://doi.org/ 10.1093/jac/dkq260.

22. Patsopoulos NA, Ntzani EE, Zintzaras E, Ioannidis J. CYP2D6 polymorphisms and the risk of tardive dyskinesia in schizophrenia: a meta-analysis. Pharmacogenet Genomics.
2005;15(3):151-8. https://doi.org/10.1097/01213011-20050300000003.

23. Parkman HP, Mishra A, Jacobs M, Pathikonda M, Sachdeva P, Gaughan J, et al. Clinical response and side effects of metoclopramide associations with clinical, demographic, and pharmacogenetic parameters. J Clin Gastroenterol. 2012;46(6):494-503. https://doi.org/10.1097/MCG.0b013e3182522624.

24. Morgan MY, Reshef R, Shah RR, Oates NS, Smith RL, Sherlock S. Impaired oxidation of debrisoquine in patients with Perhexiline liver-injury. Gut. 1984;25(10):1057-64. https:// doi.org/10.1136/gut.25.10.1057.

25. Lee AM, Shi Q, Pavey E, Alberts SR, Sargent DJ, Sinicrope FA, et al. DPYD variants as predictors of 5-fluorouracil toxicity in adjuvant colon cancer treatment (NCCTG N0147). J Natl Cancer Inst. 2014;106(12). doi: https://doi.org/10.1093/ jnci/dju298.

26. Huang Y-S, Su W-J, Huang Y-H, Chen C-Y, Chang F-Y, Lin H$\mathrm{C}$, et al. Genetic polymorphisms of manganese superoxide dismutase, NAD(P)H:quinone oxidoreductase, glutathione Stransferase M1 and T1, and the susceptibility to drug-induced liver injury. J Hepatol. 2007;47(1):128-34. https://doi.org/ 10.1016/j.jhep.2007.02.009.

27. Leiro V, Fernández-Villar A, Valverde D, Constenla L, Vázquez R, Piñeiro L, et al. Influence of glutathione Stransferase M1 and T1 homozygous null mutations on the risk of antituberculosis drug-induced hepatotoxicity in a Caucasian population. Liver Int. 2008;28(6):835-9. https://doi.org/10.1111/ j.1478-3231.2008.01700.x.

28. Innocenti $\mathrm{F}$, Undevia SD, Iyer $\mathrm{L}$, Chen PX, Das S, Kocherginsky $M$, et al. Genetic variants in the UDPglucuronosyltransferase $1 \mathrm{~A} 1$ gene predict the risk of severe neutropenia of irinotecan. J Clin Oncol. 2004;22(8):1382-8. https://doi.org/10.1200/JCO.2004.07.173.

29. Daly AK, Aithal GP, Leathart JBS, Swainsbury RA, Dang TS, Day CP. Genetic susceptibility to diclofenac-induced hepatotoxicity: contribution of UGT2B7, CYP2C8, and $\mathrm{ABCC} 2$ genotypes. Gastroenterology. 2007;132(1):272-81. https:// doi.org/10.1053/j.gastro.2006.11.023.

30. Nguyen CM, Mendes MAS, Ma JD. Thiopurine methyltransferase (TPMT) genotyping to predict myelosuppression risk. PLoS Currents. 2011;3:RRN1236-7. https://doi.org/10.1371/ currents.RRN1236.

31. SEARCH Collaborative Group, Link E, Parish S, Armitage J, Bowman L, Heath S, et al. SLCO1B1 variants and statininduced myopathy - a genomewide study. N Engl J Med. 2008;359(8):789-99. https://doi.org/10.1056/NEJMoa0801936 .

32. Daly AK, Donaldson PT, Bhatnagar P, Shen Y, Pe'er I, Floratos A, et al. HLA-B*5701 genotype is a major determinant of drug-induced liver injury due to flucloxacillin. Nat Genet. 2009;41(7):816-9. https://doi.org/10.1038/ng.379.

33. Kindmark A, Jawaid A, Harbron CG, Barratt BJ, Bengtsson OF, Andersson TB, et al. Genome-wide pharmacogenetic investigation of a hepatic adverse event without clinical signs of immunopathology suggests an underlying immune pathogenesis. Pharmacogenomics J. 2007;8(3):186-95. https://doi.org/ 10.1038/sj.tpj.6500458.

34. Hautekeete ML, Horsmans Y, van Waeyenberge C, Demanet C, Henrion J, Verbist L, et al. HLA association of amoxicillinclavulanate-induced hepatitis. Gastroenterology. 1999;117(5):11816. https://doi.org/10.1016/S0016-5085(99)70404-X.

35. Hirata K, Takagi H, Yamamoto M, Matsumoto T, Nishiya T, Mori K, et al. Ticlopidine-induced hepatotoxicity is associated with specific human leukocyte antigen genomic subtypes in Japanese patients: a preliminary case-control study. Pharmacogenomics J. 2007;8(1):29-33. https://doi.org/10.1038/ sj.tpj.6500442.

36. Singer JB, Lewitzky S, Leroy E, Yang F, Zhao X, Klickstein L, et al. A genome-wide study identifies HLA alleles associated with lumiracoxib-related liver injury. Nat Genet. 2010;42(8):711-4. https://doi.org/10.1038/ng.632.

37. Mallal S, Nolan D, Witt C, Masel G, Martin AM, Moore C, et al. Association between presence of HLA-B*5701, HLADR7, and HLA-DQ3 and hypersensitivity to HIV-1 reversetranscriptase inhibitor abacavir. Lancet. 2002;359(9308):72732. https://doi.org/10.1016/S0140-6736(02)07873-X. 
38. Ozeki T, Mushiroda T, Yowang A, Takahashi A, Kubo M, Shirakata Y, et al. Genome-wide association study identifies HLA-A*3101 allele as a genetic risk factor for carbamazepineinduced cutaneous adverse drug reactions in Japanese population. Hum Mol Genet. 2011;20(5):1034-41. https://doi.org/ $10.1093 / \mathrm{hmg} / \mathrm{ddq} 537$.

39. Locharernkul C, Loplumlert J, Limotai C, Korkij W, Desudchit T, Tongkobpetch S, et al. Carbamazepine and phenytoin induced Stevens-Johnson syndrome is associated with HLA-B*1502 allele in Thai population. Epilepsia. 2008;49(12):2087-91. https:// doi.org/10.1111/j.1528-1167.2008.01719.x.

40. Hung S-I, Chung W-H, Liou L-B, Chu C-C, Lin M, Huang H$\mathrm{P}$, et al. HLA-B*5801 allele as a genetic marker for severe cutaneous adverse reactions caused by allopurinol. Proc Natl Acad Sci. 2005;102(11):4134-9. https://doi.org/10.1073/ pnas.0409500102.

41. Cornejo Castro EM, Carr DF, Jorgensen AL, Alfirevic A, Pirmohamed M. HLA-allelotype associations with nevirapineinduced hypersensitivity reactions and hepatotoxicity. Pharmacogenet Genomics. 2015;25(4):186-98. https://doi.org/ 10.1097/FPC.0000000000000124.

42. Carr DF, Chaponda M, Jorgensen AL, Castro EC, van Oosterhout JJ, Khoo SH, et al. Association of human leukocyte antigen alleles and nevirapine hypersensitivity in a Malawian HIV-infected population. Clin Infect Dis : Off Publ Infect Dis Soc Am. 2013;56(9):1330-9. https://doi.org/10.1093/ $\mathrm{cid} / \mathrm{cit} 021$.

43. Takeuchi F, McGinnis R, Bourgeois S, Barnes C, Eriksson N, Soranzo N, et al. A genome-wide association study confirms VKORC1, CYP2C9, and CYP4F2 as principal genetic determinants of warfarin dose. PLoS Genet. 2009;5(3):e1000433-9. https://doi.org/10.1371/journal.pgen.1000433.

44. Shuldiner AR, O'Connell JR, Bliden KP, Gandhi A, Ryan K, Horenstein RB, et al. Association of cytochrome P450 2C19 genotype with the antiplatelet effect and clinical efficacy of clopidogrel therapy. JAMA. 2009;302(8):849-57. https:// doi.org/10.1001/jama.2009.1232.

45. Furuta T, Shirai N, Takashima M, Xiao F, Hanai H, Sugimura $\mathrm{H}$, et al. Effect of genotypic differences in CYP2C19 on cure rates for Helicobacter pylori infection by triple therapy with a proton pump inhibitor, amoxicillin, and clarithromycin. Clin Pharmacol Ther. 2001;69(3):158-68. https://doi.org/10.1067/ mcp.2001.113959.

46. Chasman DI, Giulianini F, MacFadyen J, Barratt BJ, Nyberg F, Ridker PM. Genetic determinants of statin-induced low-density lipoprotein cholesterol reduction: the justification for the use of statins in prevention: an intervention trial evaluating Rosuvastatin (JUPITER) trial. Circ Cardiovasc Genet. 2012;5(2):257-64. https:// doi.org/10.1161/CIRCGENETICS.111.961144.

47. Cutting GR. Cystic fibrosis genetics: from molecular understanding to clinical application. Nat Rev Genet. 2014;16(1):4556. https://doi.org/10.1038/nrg3849.

48. Carter SC, McKone EF. Pharmacogenetics of cystic fibrosis treatment. Pharmacogenomics. 2016;17(13):1453-63. https:// doi.org/10.2217/pgs.16.25.

49. Wang L, McLeod HL, Weinshilboum RM. Genomics and drug response. N Engl J Med. 2011;364(12):1144-53. https://doi.org/ 10.1056/NEJMra1010600.

50. Pirmohamed M. Personalized pharmacogenomics: predicting efficacy and adverse drug reactions. Annu Rev Genomics Hum Genet. 2014;15(1):349-70. https://doi.org/10.1146/annurevgenom-090413-025419.

51. Hertz DL, Rae J. Pharmacogenetics of cancer drugs. Annu Rev Med. 2015;66(1):65-81. https://doi.org/10.1146/annurevmed-053013-053944.

52. Kelly LE, Rieder M, van den Anker J, Malkin B, Ross C, Neely MN, et al. More codeine fatalities after tonsillectomy in North American children. Pediatrics. 2012;129(5):e1343-7. https://doi.org/10.1542/peds.2011-2538.

53. Baugh RF, Archer SM, Mitchell RB, Rosenfeld RM, Amin R, Burns JJ, et al. Clinical practice guideline: tonsillectomy in children. 2011. p. S1-30.

54. Aithal GP, Day CP, Kesteven PJ, Daly AK. Association of polymorphisms in the cytochrome P450 CYP2C9 with warfarin dose requirement and risk of bleeding complications. Lancet.
1999;353(9154):717-9. https://doi.org/10.1016/S01406736(98)04474-2.

55. Higashi MK, Veenstra DL, Kondo LM, Wittkowsky AK, Srinouanprachanh SL, Farin FM, et al. Association between CYP2C9 genetic variants and anticoagulation-related outcomes during warfarin therapy. JAMA. 2002;287(13):1690-8. https://doi.org/10.1001/jama.287.13.1690.

56. Rost S, Fregin A, Ivaskevicius V, Conzelmann E, Hörtnagel K, Pelz H-J, et al. Mutations in VKORC1 cause warfarin resistance and multiple coagulation factor deficiency type 2. Nature. 2004:427(6974):537-41. https://doi.org/10.1038/nature02214.

57. Rieder MJ, Reiner AP, Gage BF, Nickerson DA, Eby CS, McLeod HL, et al. Effect of VKORC1 haplotypes on transcriptional regulation and warfarin dose. $\mathrm{N}$ Engl J Med. 2005;352(22):2285-93. https://doi.org/10.1056/NEJMoa044503.

58. Anderson JL, Horne BD, Stevens SM, Woller SC, Samuelson KM, Mansfield JW, et al. A randomized and clinical effectiveness trial comparing two pharmacogenetic algorithms and standard care for individualizing warfarin dosing (CoumaGen-II). Circulation. 2012;125(16):1997-2005. https:// doi.org/10.1161/CIRCULATIONAHA.111.070920.

59. Pirmohamed M, Burnside G, Eriksson N, Jorgensen AL, Toh $\mathrm{CH}$, Nicholson T, et al. A randomized trial of genotype-guided dosing of warfarin. N Engl J Med. 2013;369(24):2294-303. https://doi.org/10.1056/NEJMoa1311386.

60. Kimmel SE, French B, Kasner SE, Johnson JA, Anderson JL, Gage BF, et al. A pharmacogenetic versus a clinical algorithm for warfarin dosing. N Engl J Med. 2013;369(24):2283-93. https://doi.org/10.1056/NEJMoa1310669.

61. Hetherington S, McGuirk S, Powell G, Cutrell A, Naderer O, Spreen B, et al. Hypersensitivity reactions during therapy with the nucleoside reverse transcriptase inhibitor abacavir. Clin Ther. 2001;23(10):1603-14. https://doi.org/10.1016/s01492918(01)80132-6.

62. Mallal S, Phillips E, Carosi G, Molina J-M, Workman C, Tomazic J, et al. HLA-B*5701 screening for hypersensitivity to abacavir. N Engl J Med. 2008;358(6):568-79. https://doi.org/ 10.1056/NEJMoa0706135.

63. Illing PT, Vivian JP, Dudek NL, Kostenko L, Chen Z, Bharadwaj $\mathrm{M}$, et al. Immune self-reactivity triggered by drugmodified HLA-peptide repertoire. Nature. 2012;486(7404):554-8. https://doi.org/10.1038/nature11147.

64. Chessman D, Kostenko L, Lethborg T, Purcell AW, Williamson NA, Chen Z, et al. Human leukocyte antigen class I-restricted activation of $\mathrm{CD} 8+\mathrm{T}$ cells provides the immunogenetic basis of a systemic drug hypersensitivity. Immunity. 2008;28(6):822-32. https://doi.org/10.1016/j.immuni.2008.04.020.

65. Swen JJ, Nijenhuis M, de Boer A, Grandia L, der Zee AHM$\mathrm{V}$, Mulder $\mathrm{H}$, et al. Pharmacogenetics: from bench to byte-an update of guidelines. Clin Pharmacol Ther. 2009;89(5):662-73. https://doi.org/10.1038/clpt.2011.34.

66. Martin MA, Hoffman JM, Freimuth RR, Klein TE, Dong BJ, Pirmohamed M, et al. Clinical pharmacogenetics implementation consortium guidelines for HLA-B genotype and abacavir dosing: 2014 update. Clin Pharmacol Ther. 2014;95(5):499-500. https://doi.org/10.1038/clpt.2014.38.

67. Relling MV, Hancock ML, Rivera GK, Sandlund JT, Ribeiro RC, Krynetski EY, et al. Mercaptopurine therapy intolerance and heterozygosity at the thiopurine S-methyltransferase gene locus. JNCI J Natl Cancer Inst. 1999;91(23):2001-8. https:// doi.org/10.1093/jnci/91.23.2001.

68. Karas-Kuzelicki N, Jazbec J, Milek M, Mlinaric-Rascan I. Heterozygosity at the TPMT gene locus, augmented by mutated MTHFR gene, predisposes to 6-MP related toxicities in childhood ALL patients. Leukemia. 2009;23(5):971-4. https://doi.org/10.1038/leu.2008.317.

69. Colletti RB, Baldassano RN, Milov DE, Margolis PA, Bousvaros A, Crandall WV, et al. Variation in care in pediatric Crohn disease. J Pediatr Gastroenterol Nutr. 2009;49(3):297303. https://doi.org/10.1097/MPG.0b013e3181919695.

70. Fargher EA, Tricker K, Newman W, Elliott R, Roberts SA, Shaffer JL, et al. Current use of pharmacogenetic testing: a national survey of thiopurine methyltransferase testing prior to azathioprine prescription. J Clin Pharm Ther. 2007;32(2):18795. https://doi.org/10.1111/j.1365-2710.2007.00805.x. 
71. Compagni A, Bartoli S, Buehrlen B, Fattore G, Ibarreta D, de Mesa EG. Avoiding adverse drug reactions by pharmacogenetic testing: a systematic review of the economic evidence in the case of TPMT and AZA-induced side effects. Int J Technol Assess Health Care. 2008;24(3):294-302. https://doi.org/ 10.1017/S0266462308080392.

72. Plumpton CO, Roberts D, Pirmohamed M, Hughes DA. A systematic review of economic evaluations of pharmacogenetic testing for prevention of adverse drug reactions. PharmacoEconomics. 2016;34(8):771-93. https://doi.org/ 10.1007/s40273-016-0397-9.

73. FDA Drug Safety Communication: new restrictions, contraindications, and dose limitations for Zocor (simvastatin) to reduce the risk of muscle injury; https://www.fda.gov/Drugs/ DrugSafety/ucm256581.htm [Accessed 29.06.2017].

74. Wilson PM, Danenberg PV, Johnston PG, Lenz H-J, Ladner RD. Standing the test of time: targeting thymidylate biosynthesis in cancer therapy. Nat Rev Clin Oncol. 2014;11(5):28298. https://doi.org/10.1038/nrclinonc.2014.51.

75. Gamelin E, Delva R, Jacob J, Merrouche Y, Raoul JL, Pezet $\mathrm{D}$, et al. Individual fluorouracil dose adjustment based on pharmacokinetic follow-up compared with conventional dosage: results of a multicenter randomized trial of patients with metastatic colorectal cancer. J Clin Oncol. 2008;26(13):2099_ 105. https://doi.org/10.1200/JCO.2007.13.3934.

76. Diasio RB, Harris BE. Clinical-pharmacology of 5-fluorouracil. Clin Pharmacokinet. 1989;16(4):215-37. https://doi.org/10.2165/ 00003088-198916040-00002.

77. Deenen MJ, Meulendijks D, Cats A, Sechterberger MK, Severens JL, Boot H, et al. Upfront genotyping of DPYD* 2Ato individualize fluoropyrimidine therapy: a safety and cost analysis. J Clin Oncol. 2016;34(3):227-34. https://doi.org/ 10.1200/JCO.2015.63.1325.

78. Matthaei J, Brockmöller J, Tzvetkov MV, Sehrt D, SachseSeeboth C, Hjelmborg JB, et al. Heritability of metoprolol and torsemide pharmacokinetics. Clin Pharmacol Ther. 2015;98(6):611-21. https://doi.org/10.1002/cpt.258.

79. Matthaei J, Tzvetkov MV, Gal V, Sachse-Seeboth C, Sehrt D, Hjelmborg JB, et al. Low heritability in pharmacokinetics of talinolol: a pharmacogenetic twin study on the heritability of the pharmacokinetics of talinolol, a putative probe drug of MDR1 and other membrane transporters. Genome Med. 2016;1-12. doi: https://doi.org/10.1186/s13073-016-0372-2.

80. Fujikura K, Ingelman-Sundberg M, Lauschke VM. Genetic variation in the human cytochrome P450 supergene family. Pharmacogenet Genomics. 2015;25(12):584-94. https://doi.org/ 10.1097/FPC.0000000000000172.

81. Kozyra M, Ingelman-Sundberg M, Lauschke VM. Rare genetic variants in cellular transporters, metabolic enzymes, and nuclear receptors can be important determinants of interindividual differences in drug response. Genet Med. 2017;19(1):20-9. https://doi.org/10.1038/gim.2016.33.

82. 1000 Genomes Project Consortium. An integrated map of genetic variation from 1,092 human genomes. Nature. 2012;491(7422):56-65. https://doi.org/10.1038/nature11632 .

83. Tennessen JA, Bigham AW, O'Connor TD, Fu W, Kenny EE, Gravel S, et al. Evolution and functional impact of rare coding variation from deep sequencing of human exomes. Science. 2012;337(6090):64-9. https://doi.org/10.1126/science.1219240.

84. Lek M, Karczewski KJ, Minikel EV, Samocha KE, Banks E, Fennell T, et al. Analysis of protein-coding genetic variation in 60,706 humans. Nature. 2016;536(7616):285-91. https://doi.org/ 10.1038/nature19057

85. 1000 Genomes Project Consortium. A global reference for human genetic variation. Nature. 2015;526(7571):68-74. https://doi.org/10.1038/nature15393.

86. Apellaniz-Ruiz M, Inglada-Pérez L, Naranjo MEG, Sánchez L, Mancikova V, Currás-Freixes $M$, et al. High frequency and founder effect of the CYP3A4*20 loss-of-function allele in the Spanish population classifies CYP3A4 as a polymorphic enzyme. Pharmacogenomics J. 2015;15(3):288-92. https:// doi.org/10.1038/tpj.2014.67.

87. Nyakutira C, Röshammar D, Chigutsa E, Chonzi P, Ashton M, Nhachi C, et al. High prevalence of the CYP2B6 516G?T(*6) variant and effect on the population pharmacokinetics of efavirenz in HIV/AIDS outpatients in Zimbabwe. Eur J Clin Pharmacol. 2007;64(4):357-65. https://doi.org/10.1007/s00228007-0412-3.

88. Roederer MW, McLeod HL. Applying the genome to national drug formulary policy in the developing world. Pharmacogenomics. 2010;11(5):633-6. https://doi.org/10.2217/ pgs.10.55.

89. Roederer MW, Sanchez-Giron F, Kalideen K, Kudzi W, McLeod HL, Zhang W. Pharmacogenetics and rational drug use around the world. Pharmacogenomics. 2011;12(6):897-905. https://doi.org/10.2217/pgs.11.17.

90. Lauschke VM, Ingelman-Sundberg M. Precision medicine and rare genetic variants. Trends Pharmacol Sci. 2016;37(2):85-6. https://doi.org/10.1016/j.tips.2015.10.006.

91. Peterson TA, Doughty E, Kann MG. Towards precision medicine: advances in computational approaches for the analysis of human variants. J Mol Biol. 2013;425(21):4047-63. https://doi.org/10.1016/j.jmb.2013.08.008.

92. Kumar P, Henikoff S, Ng PC. Predicting the effects of coding non-synonymous variants on protein function using the SIFT algorithm. Nat Protoc. 2009;4(8):1073-81. https://doi.org/ 10.1038/nprot.2009.86.

93. Adzhubei IA, Schmidt S, Peshkin L, Ramensky VE, Gerasimova A, Bork P, et al. A method and server for predicting damaging missense mutations. Nat Methods. 2010;7(4):248-9. https://doi.org/10.1038/nmeth0410-248.

94. Choi Y, Sims GE, Murphy S, Miller JR, Chan AP. Predicting the functional effect of amino acid substitutions and indels. PLoS One. 2012;7(10):e46688-13. https://doi.org/10.1371/ journal.pone.0046688.

95. Quang D, Chen Y, Xie X. DANN: a deep learning approach for annotating the pathogenicity of genetic variants. Bioinformatics. 2015;31(5):761-3. https://doi.org/10.1093/bioinformatics/btu703.

96. GBD 2015 Disease and Injury Incidence and Prevalence Collaborators. Global, regional, and national incidence, prevalence, and years lived with disability for 310 diseases and injuries, 1990-2015: a systematic analysis for the Global Burden of Disease Study 2015. Lancet (London, England). 2016;388(10053):1545-602. https://doi.org/10.1016/S01406736(16)31678-6

97. Jones S, Wang T-L, Shih I-M, Mao T-L, Nakayama K, Roden $\mathrm{R}$, et al. Frequent mutations of chromatin remodeling gene ARID1A in ovarian clear cell carcinoma. Science. 2010;330(6001):228-31. https://doi.org/10.1126/science.1196333.

98. Fujimoto A, Totoki Y, Abe T, Boroevich KA, Hosoda F, Nguyen $\mathrm{HH}$, et al. Whole-genome sequencing of liver cancers identifies etiological influences on mutation patterns and recurrent mutations in chromatin regulators. Nat Genet. 2012;44(7):760-4. https://doi.org/10.1038/ng.2291.

99. Kleer CG, Cao Q, Varambally S, Shen RL, Ota L, Tomlins SA, et al. EZH2 is a marker of aggressive breast cancer and promotes neoplastic transformation of breast epithelial cells. Proc Natl Acad Sci. 2003;100(20):11606-11. https://doi.org/ 10.1073/pnas.1933744100.

100. Sneeringer CJ, Scott MP, Kuntz KW, Knutson SK, Pollock RM, Richon VM, et al. Coordinated activities of wild-type plus mutant EZH2 drive tumor-associated hypertrimethylation of lysine 27 on histone H3 (H3K27) in human B-cell lymphomas. Proc Natl Acad Sci U S A. 2010;107(49):20980-5. https:// doi.org/10.1073/pnas.1012525107.

101. Schutte M, Hruban RH, Geradts J, Maynard R, Hilgers W, Rabindran SK, et al. Abrogation of the Rb/p16 tumorsuppressive pathway in virtually all pancreatic carcinomas. Cancer Res. 1997;57(15):3126-30.

102. Scaltriti M, Eichhorn PJ, Cortés J, Prudkin L, Aura C, Jiménez $\mathrm{J}$, et al. Cyclin $\mathrm{E}$ amplification/overexpression is a mechanism of trastuzumab resistance in HER2+ breast cancer patients. Proc Natl Acad Sci U S A. 2011;108(9):3761-6. https://doi.org/ 10.1073/pnas.1014835108.

103. Lu C, Ward PS, Kapoor GS, Rohle D, Turcan S, Abdel-Wahab $\mathrm{O}$, et al. IDH mutation impairs histone demethylation and results in a block to cell differentiation. Nature. 2012;483(7390):474-8. https://doi.org/10.1038/nature10860. 
104. Babina IS, Turner NC. Advances and challenges in targeting FGFR signalling in cancer. Nat Rev Cancer. 2017;17(5):318-32. https://doi.org/10.1038/nrc.2017.8.

105. Sequist LV, Yang JC-H, Yamamoto N, O’Byrne K, Hirsh V, Mok T, et al. Phase III study of afatinib or cisplatin plus pemetrexed in patients with metastatic lung adenocarcinoma with EGFRMutations. J Clin Oncol. 2013;31(27):3327-34. https://doi.org/10.1200/JCO.2012.44.2806.

106. Rosell R, Carcereny E, Gervais R, Vergnenegre A, Massuti B, Felip E, et al. Erlotinib versus standard chemotherapy as firstline treatment for European patients with advanced EGFR mutation-positive non-small-cell lung cancer (EURTAC): a multicentre, open-label, randomised phase 3 trial. Lancet Oncol. 2012;13(3):239-46. https://doi.org/10.1016/S14702045(11)70393-X

107. Maemondo M, Inoue A, Kobayashi K, Sugawara S, Oizumi S, Isobe $\mathrm{H}$, et al. Gefitinib or chemotherapy for non-small-cell lung cancer with mutated EGFR. N Engl J Med. 2010;362(25):2380-8. https://doi.org/10.1056/NEJMoa0909530.

108. Brown PD, Krishnan S, Sarkaria JN, Wu W, Jaeckle KA, Uhm $\mathrm{JH}$, et al. Phase I/II trial of erlotinib and temozolomide with radiation therapy in the treatment of newly diagnosed glioblastoma multiforme: North Central Cancer Treatment Group Study N0177. J Clin Oncol. 2008;26(34):5603-9. https://doi.org/ 10.1200/JCO.2008.18.0612.

109. Kobayashi S, Boggon TJ, Dayaram T, Janne PA, Kocher O, Meyerson M, et al. EGFR mutation and resistance of nonsmall-cell lung cancer to gefitinib. $N$ Engl J Med. 2005;352(8):786-92. https://doi.org/10.1056/NEJMoa044238.

110. Mok TS, Wu Y-L, Ahn M-J, Garassino MC, Kim HR, Ramalingam SS, et al. Osimertinib or platinum-pemetrexed in EGFR T790M-positive lung cancer. N Engl J Med. 2017;376(7):629-40. https://doi.org/10.1056/NEJMoa1612674.

111. O'Brien SG, Guilhot F, Larson RA, Gathmann I, Baccarani M, Cervantes $\mathrm{F}$, et al. Imatinib compared with interferon and lowdose cytarabine for newly diagnosed chronic-phase chronic myeloid leukemia. N Engl J Med. 2003;348(11):994-1004. https://doi.org/10.1056/NEJMoa022457.

112. Hochhaus A, La Rosée P. Imatinib therapy in chronic myelogenous leukemia: strategies to avoid and overcome resistance. Leukemia. 2004;18(8):1321-31. https://doi.org/ 10.1038/sj.leu.2403426.

113. An X, Tiwari AK, Sun Y, Ding P-R, Ashby CR Jr, Chen Z-S. BCR-ABL tyrosine kinase inhibitors in the treatment of Philadelphia chromosome positive chronic myeloid leukemia: a review. Leuk Res. 2010;34(10):1255-68. https://doi.org/ 10.1016/j.leukres.2010.04.016.

114. O'Hare T, Walters DK, Stoffregen EP, Jia TP, Manley PW, Mestan J, et al. In vitro activity of Bcr-Abl inhibitors AMN107 and BMS-354825 against clinically relevant imatinib-resistant Abl kinase domain mutants. Cancer Res. 2005;65(11):4500-5. https://doi.org/10.1158/0008-5472.CAN-05-0259.

115. Cortes JE, Kim DW, Pinilla-Ibarz J, le Coutre P, Paquette R, Chuah C, et al. A phase 2 trial of ponatinib in Philadelphia chromosome-positive leukemias. N Engl J Med. 2013;369(19):1783-96. https://doi.org/10.1056/NEJMoa1306494.

116. Ding L, Wendl MC, McMichael JF, Raphael BJ. Expanding the computational toolbox for mining cancer genomes. Nat Rev Genet. 2014;15(8):556-70. https://doi.org/10.1038/nrg3767.

117. Schilsky RL. Implementing personalized cancer care. Nat Rev Clin Oncol. 2014;11(7):432-8. https://doi.org/10.1038/ nrclinonc.2014.54.

118. Tattini L, D Aurizio R, Magi A. Detection of genomic structural variants from next-generation sequencing data Front Bioeng Biotechnol. 2015;3:1-8. https://doi.org/10.3389/ fbioe.2015.00092.

119. Carneiro MO, Russ C, Ross MG, Gabriel SB, Nusbaum C, DePristo MA. Pacific biosciences sequencing technology for genotyping and variation discovery in human data. BMC Genomics. 2012;13(1):375. https://doi.org/10.1186/1471-2164-13-375.
120. Pendleton M, Sebra R, Pang AWC, Ummat A, Franzen O, Rausch T, et al. Assembly and diploid architecture of an individual human genome via single-molecule technologies. Nat Methods. 2015;12(8):780-6. https://doi.org/10.1038/nmeth.3454.

121. Eid J, Fehr A, Gray J, Luong K, Lyle J, Otto G, et al. Realtime DNA sequencing from single polymerase molecules. Science. 2009;323(5910):133-8. https://doi.org/10.1126/ science.1162986.

122. Qiao W, Yang Y, Sebra R, Mendiratta G, Gaedigk A, Desnick $\mathrm{RJ}$, et al. Long-read single molecule real-time full gene sequencing of cytochrome P450-2D6. Hum Mutat. 2016;37(3):315-23. https://doi.org/10.1002/humu.22936.

123. Buermans HPJ, Vossen RHAM, Anvar SY, Allard WG, Guchelaar H-J, White SJ, et al. Flexible and scalable fulllength CYP2D6 long amplicon PacBio sequencing. Hum Mutat. 2017;38(3):310-6. https://doi.org/10.1002/humu.23166.

124. Wu TP, Wang T, Seetin MG, Lai Y, Zhu S, Lin K, et al. DNA methylation onN6-adenine in mammalian embryonic stem cells. Nature. 2016;532(7599):329-33. https://doi.org/10.1038/ nature 17640

125. Clarke J, Wu H-C, Jayasinghe L, Patel A, Reid S, Bayley H. Continuous base identification for single-molecule nanopore DNA sequencing. Nat Nanotechnol. 2009;4(4):265-70. https:// doi.org/10.1038/nnano.2009.12.

126. Simpson JT, Workman RE, Zuzarte PC, David M, Dursi LJ, Timp W. Detecting DNA cytosine methylation using nanopore sequencing. Nat Methods. 2017;14(4):407-10. https://doi.org/ 10.1038/nmeth. 4184 .

127. Karamitros T, Magiorkinis G. A novel method for the multiplexed target enrichment of MinION next generation sequencing libraries using PCR-generated baits. Nucleic Acids Res. 2015;43(22):e152-e. https://doi.org/10.1093/nar/gkv773.

128. Dapprich J, Ferriola D, Mackiewicz K, Clark PM, Rappaport E, D'Arcy M, et al. The next generation of target capture technologies-large DNA fragment enrichment and sequencing determines regional genomic variation of high complexity. BMC Genomics. 2016;1-14. doi: https://doi.org/10.1186/s12864016-2836-6.

129. Loose M, Malla S, Stout M. Real-time selective sequencing using nanopore technology. Nat Methods. 2016;13(9):751-4. https://doi.org/10.1038/nmeth.3930.

130. Adey A, Kitzman JO, Burton JN, Daza R, Kumar A, Christiansen $\mathrm{L}$, et al. In vitro, long-range sequence information for de novo genome assembly via transposase contiguity. Genome Res. 2014;24(12):2041-9. https://doi.org/10.1101/ gr.178319.114.

131. Bishara A, Liu Y, Weng Z, Kashef-Haghighi D, Newburger $\mathrm{DE}$, West $\mathrm{R}$, et al. Read clouds uncover variation in complex regions of the human genome. Genome Res. 2015;25(10):1570-80. https://doi.org/10.1101/gr.191189.115.

132. Ehmann F, Caneva L, Prasad K, Paulmichl M, Maliepaard M, Llerena A, et al. Pharmacogenomic information in drug labels: European Medicines Agency perspective. Pharmacogenomics J. 2015;15(3):201-10. https://doi.org/10.1038/tpj.2014.86.

133. Patrinos GP, Mitropoulou C. Measuring the value of pharmacogenomics evidence. Clin Pharmacol Ther. 2017;15(5):349-3. https://doi.org/10.1002/cpt.743.

134. van der Wouden $\mathrm{CH}$, Cambon-Thomsen $\mathrm{A}$, Cecchin E, Cheung KC, Dávila-Fajardo CL, Deneer VH, et al. Implementing pharmacogenomics in Europe: design and implementation strategy of the ubiquitous pharmacogenomics consortium. Clin Pharmacol Ther. 2017;101(3):341-58. https:// doi.org/10.1002/cpt.602.

135. Dunnenberger HM, Crews KR, Hoffman JM, Caudle KE, Broeckel U, Howard SC, et al. Preemptive clinical pharmacogenetics implementation: current programs in five US medical centers. Annu Rev Pharmacol Toxicol. 2015;55(1):89-106. https://doi.org/10.1146/annurev-pharmtox-010814-124835.

136. Lauschke VM, Ingelman-Sundberg M. Requirements for comprehensive pharmacogenetic genotyping platforms. Pharmacogenomics. 2016;17(8):917-24. https://doi.org/10.2217/pgs-2016-0023. 